\title{
Cross-cultural comparison of m-commerce adoption between developed and developing countries: A literature review
}

\author{
Mohammed Mizanur Rahman ${ }^{\text {** }}$, Terry Sloan $^{2}$ \\ ${ }^{I}$ Business Administration, Arab Open University Bahrain \\ PO BOX 18211, Bahrain Mall, Manama, Kingdom of Bahrain \\ Email: mizan1214@yahoo.com.au \\ ${ }^{2}$ School of Business, University of Western Sydney \\ Locked Bag 1797, Penrith, NSW, Australia 2751 \\ Email: t.slaon@uws.edu.au
}

\begin{abstract}
The purpose of this paper is to report a review of literature that dealt with the factors affecting $\mathrm{m}$ commerce adoption, and comparing the reported differences in outcomes between developed and developing countries. 42 empirical research papers reporting on these key factors were examined, and categorized into either developed or developing countries in order to compare the outcomes. On average the outcomes of these studies were found to be more contradictory in developing countries than in developed countries; particularly for some key factors such as perceived ease of use, awareness, selfefficacy and enjoyment where disagreement was the highest in developing countries. Also, some factors were found to be studied in developing countries but never studied in developed countries and vice versa. We suggest that more research is required on the factors that resulted in contradictory findings.
\end{abstract}

Keywords: m-commerce, e-commerce adoption, key factors, developed and developing countries.

\section{Introduction}

M-commerce is defined as mobile e-commerce ${ }^{1}$. According to Paavilainen m-commerce is the exchange of goods, services and information using mobile Information and Communication Technology ${ }^{2}$. Mcommerce has evolved through the convergence of the two fastest growing industries - the internet and mobile communication $^{3}$. The fundamental characteristics that differentiate m-commerce from e-commerce are ubiquity/anywhere anytime, personalization and convenience $^{4,25}$. Based on these differentiators $\mathrm{m}$ commerce is seen to be more than e-commerce since it is capable of providing almost all the services offered by e-commerce with the addition of mobility ${ }^{3}$.

A mobile phone was considered a luxury or a sign of high social status in the past, but has evolved to be a necessity at present ${ }^{5}$. Today the mobile phone has reached into the hands of 6.8 billion subscribers worldwide where more than half -3.5 billion out of 6.8 billion - are in the Asia-pacific region ${ }^{29}$. It has changed the way we do things in our life - transforming the traditional way to m-way such as m-banking, mshopping, m-wallet, $\mathrm{m}$ - advertising, m-education, magriculture, m-health, m-entertainment, m-internet, mGPS etc ${ }^{52,62}$. With the fast penetration of mobile broadband, climbing from 268 million in 2007 to 2.1 billion in $2013^{29}$; smart phones with millions of mobile applications have made $\mathrm{m}$-commerce a great potential business element in the global marketplace. Monetary transaction through mobile phone is growing fast, the volume of which crossed the $\$ 100$ billion landmark worldwide in 2011 and is expected to be $\$ 617$ billion by $2016^{52}$. With this growth the number of mobile payment users is expected to grow by $40 \%$, jumping from 1.8 billion in 2011 to 2.5 billion in $2015^{52}$.

* Corresponding author. 
There are many reasons boosting the rapid penetration of mobile phones such as necessities, convenience and ubiquities; but has m-commerce been penetrating at a similar pace? Developing countries are slightly trailing the developed countries in the case of mobile penetration, at $89 \%$ versus $128 \%$ respectively ${ }^{29}$; whereas for mobile broadband penetration, one of the key elements of m-commerce, the gap is much wider accounting for $19 \%$ in developing countries and $74 \%$ in the developed world ${ }^{30}$. In some developing countries this rate is even lower than the average with examples of $5 \%$ in Indonesia, $1.2 \%$ in Sri Lanka and $0.9 \%$ in India $^{50}$. Therefore it is necessary to identify the reasons behind the low penetration of $\mathrm{m}$-commerce, especially in developing countries, and to investigate the ways to alter that situation.

A large number of empirical studies have been undertaken in various countries to identify the factors that influence m-commerce adoption. Every country is unique in its characteristics but when categorizing them on the factors effecting m-commerce adoption, distinction can be made between developed and developing countries. Some factors that were found to be highly significant in most of the developed countries turned out to be not significant in many countries of the developing world, and vice versa. For example subjective norm and complexity were found to be highly significant by the majority of the studies in developing countries but were found to be the opposite, meaning highly insignificant, in the developed countries. Similarly awareness, self-efficacy, perceived enjoyment, quality, speed, structural assurance and customization were found to have a greater influence on the adoption of m-commerce in most of the developed countries, but were found to be of minimal effect in the developing world. Some additional factors that were studied in many parts of the developed world but not in developing countries include reputation, perceived image, behavioural control, Job relevance, selfexpressiveness, perceived playfulness, mobility, speed, management support and structural assurance. The opposite is also true; meaning some factors were studied in developing countries but not in developed countries. This second set of factors includes perceived credibility, peer influence, mobile skilfulness, perceived elitisation, rich and fast information, standardization and accessibility.

This situation calls for empirical research to study the factors that resulted in contradiction; or have never been studied before either in developed or developing countries. The current literature review has uncovered the research opportunity for the future. The next section will explain the methodology, followed by the research findings, implications, conclusion and finally future research directions.

\section{Methodology}

A review of literature is usually time consuming, especially in the field of m-commerce as relevant journal articles are scattered across various disciplines such as business, management, marketing, engineering, information technology (IT), and information systems $(\mathrm{IS})^{5}$. To minimize the time and labour 'Google Scholar' was been chosen to be the prime source of searching literature as it is linked with almost all major online journal databases, including Science Direct, Inderscience, Emerald, ABI/INFORM database, ACM digital library, IEEE Xplore, Springer link online libraries, Wiley InterScience, Scopus etc. A number of key words such as m-commerce adoption, mobile commerce adoption and factors affecting $\mathrm{m}$-commerce were used to search the potential literature.

There are many areas of m-commerce, and these have been categorised as mobile commerce applications and cases; wireless user infrastructure; mobile middleware; wireless network infrastructure; mcommerce behavioural issues; m-commerce economics; m-commerce business models; m-commerce legal and ethical issues; m-commerce overview, context, and usage ${ }^{5}$. The current study did not look at all of these areas of m-commerce research, but rather focused on the particular area of $\mathrm{m}$-commerce behavioural issues investigating how m-commerce diffusion is affected by the consumer's behaviour. Papers published before 2000 were excluded as m-commerce and its associated research has only flourished since $2000^{5}$. Initially 72 papers were collected based on a key word search. Each article was then reviewed thoroughly to see that it met the essential criteria - an empirical study that identified a number of factors affecting m-commerce adoption. Peer reviewed journals were chosen in the first round of the selection process but conference publications were also included later to enrich the review. The articles that did not match the selection criteria were excluded, and finally only 42 papers remained suitable for the current study.

\section{Results and Analysis}

Initially the accepted articles were examined and sorted based on the country studied - either developed or developing country as shown in table 1. Later the factors studied in these papers were sorted based on their outcomes, resulting in a list of factors found to be significant or not significant either in developed or developing countries, as shown in Appendix B. The information in Appendix B is also represented as a bar graph in Figure 1 to enable easy comparison between developed and developing countries. It compares the studies of 16 major factors effecting m-commerce 
adoption between developed and developing countries, with the number of studies along $\mathrm{X}$ axis and factors along $\mathrm{Y}$ axis. Dark and gray coloured bars refer to the developed and developing countries respectively. The complete list of studies represented in Appendix B and Figure 1, including the citation of each paper is given in the Appendix C. The definitions of some key factors are also presented in Appendix A.

The number of studies of m-commerce adoption is higher in developed countries than in the developing world. Out of 42 papers, 28 were based on developed countries and the remaining 14, in developing countries. In total 59 key factors were studied in those 42 research papers, where the impact of some factors (e.g. Perceived usefulness, perceived ease of use, perceived cost and perceived privacy) were found to be similar in developed and developing countries by a number of empirical studies but in case of many other factors the cases differed significantly (see Appendix C for detail).

Perceived usefulness (PU) was studied in 30 different empirical studies, 20 in developed countries and 10 in the developing world. The majority of these studies gave the same findings for PU; with 17 of the 20 studies (i.e. 85\%) in developed countries PU was found to be highly significant in the adoption of m-commerce. In the case of developing countries this ratio is $80 \%$ i.e. 8 out of 10 studies found PU to be significant for mcommerce adoption. Another important factor effecting the adoption of m-commerce or other technologies is perceived ease of use (PEOU $)^{6}$; but this was not found to be as significant as PU. The outcome of PEOU was also seen to be contradictory both in developed and developing country studies. The results for PEOU were found to be more contradictory in the developing countries than in the developed countries. 6 out of 12 studies $(50 \%)$ in the developing world found no link between PEOU and the intention (I) to use mcommerce, whereas in developed countries this ratio is dropped to $37 \%$, meaning 9 out of 24 studies found PEOU to be not significant.

\begin{tabular}{|c|c|c|}
\hline No & Developed country & Developing country \\
\hline 1 & M-commerce adoption in Finland ${ }^{8}$ & E-govt. adoption in Kuwait ${ }^{27}$ \\
\hline 2 & E-govt. adoption -US ${ }^{10}$ & M-banking adoption in India ${ }^{9}$ \\
\hline 3 & M-commerce adoption in Spain $^{11}$ & M-commerce adoption in Ghana ${ }^{12}$ \\
\hline 4 & M-payment adoption in $\mathrm{US}^{13}$ & M-commerce adoption in China $^{15}$ \\
\hline 5 & Online shopping adoption in US ${ }^{14}$ & M-banking adoption in $\mathrm{Ghana}^{20}$ \\
\hline 6 & M-internet adoption in S. Korea ${ }^{16}$ & M-commerce adoption in US \& China $^{21}$ \\
\hline 7 & E-health adoption in Hawaii ${ }^{17}$ & M-commerce adoption in Bangladesh ${ }^{3}$ \\
\hline 8 & M-commerce adoption in S. Korea ${ }^{18}$ & E-banking adoption in Bangladesh ${ }^{28}$ \\
\hline 9 & Perception in e-commerce in New Zealand ${ }^{19}$ & M-internet adoption in China ${ }^{36}$ \\
\hline 10 & M-commerce adoption in US \& China ${ }^{21}$ & M-shopping adoption in Taiwan $^{37}$ \\
\hline 11 & M-banking adoption in Australia ${ }^{22}$ & Mobile ICT adoption in sub Saharan Africa ${ }^{42}$ \\
\hline 12 & Trust on e-commerce in $\mathrm{US}^{24}$ & E-commerce adoption in S. Africa ${ }^{43}$ \\
\hline 13 & M-banking adoption in Korea $^{26}$ & M-commerce adoption in Malaysia ${ }^{61}$ \\
\hline 14 & M-commerce adoption in Hong Kong ${ }^{31}$ & M-commerce adoption in Taiwan ${ }^{63}$ \\
\hline 15 & Trust on internet banking in $\mathrm{US}^{32}$ & \\
\hline 16 & Online Shopping adoption in $\mathrm{US}^{33}$ & \\
\hline 17 & E-shopping adoption in $\mathrm{US}^{34}$ & \\
\hline 18 & Trust $\&$ risk on M-banking in $\mathrm{US}^{38}$ & \\
\hline 19 & M-commerce adoption in US $^{39}$ & \\
\hline 20 & M-ticketing adoption in Finland ${ }^{40}$ & \\
\hline 21 & M-services adoption in Norway ${ }^{45}$ & \\
\hline 22 & M-commerce adoption in Australia ${ }^{44}$ & \\
\hline 23 & Mobile multimedia adoption in Italy ${ }^{46}$ & \\
\hline 24 & E-commerce adoption $^{47}$ & \\
\hline 25 & M-parking adoption in Norway ${ }^{49}$ & \\
\hline 26 & M-internet adoption in US, Europe \& Asia $^{48}$ & \\
\hline 27 & Mobile ICT adoption in $\mathrm{UK}^{54}$ & \\
\hline 28 & User satisfaction on e-govt. in Flemish population ${ }^{60}$ & \\
\hline
\end{tabular}

Table 1: Studies on m-commerce adoption, categorized between developed and developing countries 

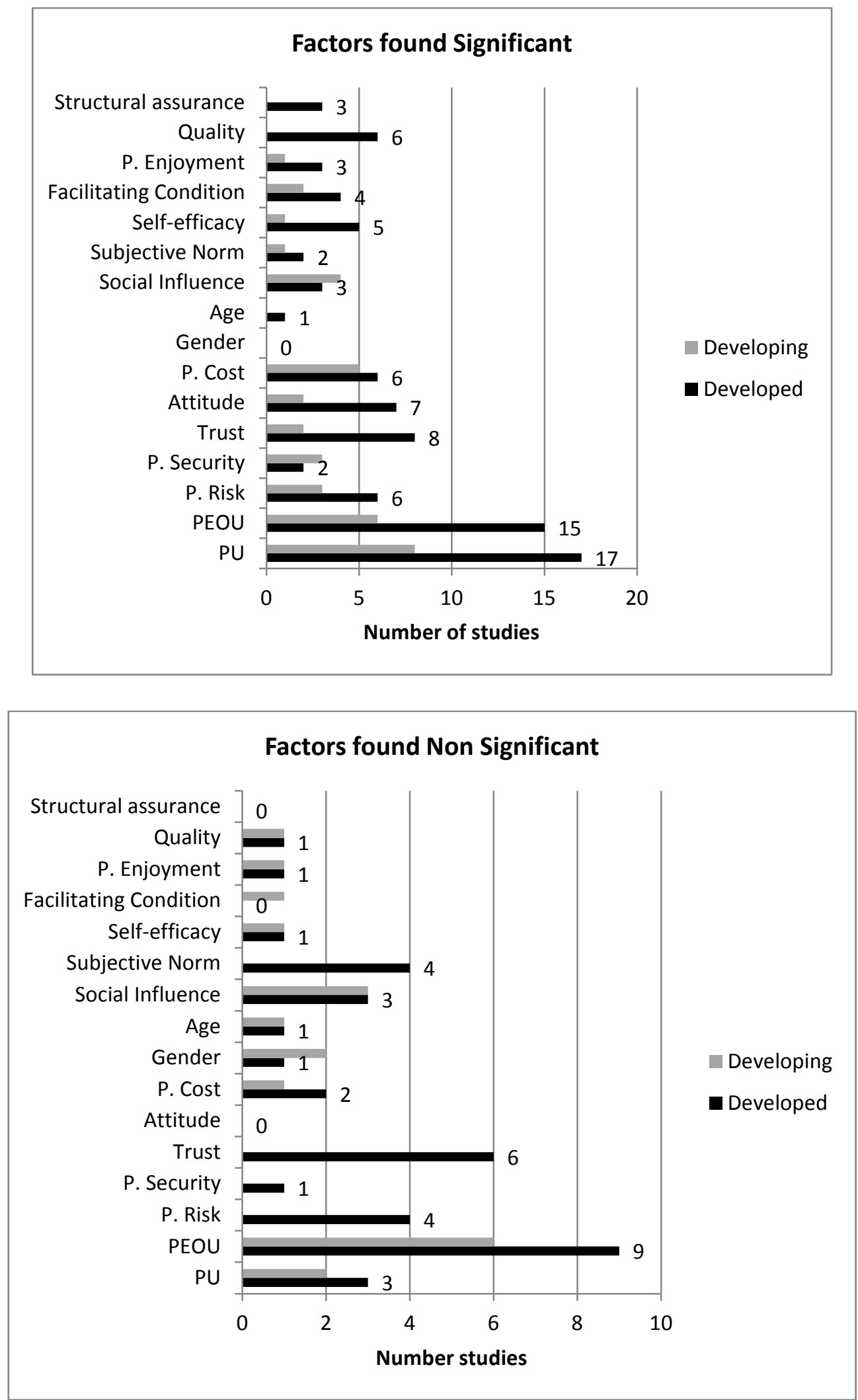

Figure 1: Factors found significant and non-significant - contrast between developed and developing countries 
Of the 10 papers studying the influence of perceived risk (PR) in developed countries, 4 of them found PR to have no significant effect in the adoption of $\mathrm{m}$ commerce. The disagreement on this issue is lower in the developing countries where all 3 papers found perceived risk to be highly significant on m-commerce adoption. This means that users in developed countries are less concerned about perceived risk than the users in developing countries. The outcome of perceived privacy is the same both in developed and developing countries with the ratio between significant and not significant being 2:1 respectively. The case of perceived security is somewhat different. Almost all the studies, 3 in developing countries and 2 in developed countries, found perceived security to be highly significant in m-commerce adoption with only exception - who studied m-commerce adoption in Finland but found perceived security to be nonsignificant ${ }^{8}$.

In some cases the factors effecting m-commerce adoption differed significantly, meaning the factors that were found to be highly significant in developing countries were found to be less significant or not significant at all in some developed countries, and vice versa. For example, factors such as 'quality' and 'awareness' were found to be highly significant by the majority of the studies in the developed countries, with 6 out of 7 studies $(85 \%)$ for 'quality' and 3 out of 3 studies $(100 \%)$ for 'awareness'. The findings were opposite when investigating these two factors for developing countries where only one paper was found to have dealt with 'quality' with no significant outcome and two papers for 'awareness' that resulted in a high level of disagreement in their findings. This means that awareness of $\mathrm{m}$-commerce is perceived to be needed for the uptake of m-commerce in developed countries but not for developing country uptake, as this was not found to be significant there. In other words, users in developing countries were found to be more aware of m-commerce services than the users in developed countries. However, users in developed countries are more concerned about the product quality than users in developing countries. Subjective norm was found to be more significant in developing countries than in developed countries. This means that consumers in developing countries are more influenced by their peers than are users in developed countries when deciding to use m-commerce services. Education was not found to be a significant factor in the adoption of $\mathrm{m}$-commerce in either developed or developing countries. Mixed results were found for age and gender in developed countries but for developing countries these factors were not found to be significant at all.

\section{Limitation}

This research faces several limitations. Firstly, it is neither a technical paper of m-commerce nor does it discuss the government policies or regulations; rather the adoption behaviour of this technology is studied across a wide range of users in both developed and developing countries. Secondly, although the keyword search was limited to m-commerce adoption, a number of papers regarding to e-commerce adoption were also brought forward by the search engine 'Google Scholar'. As m-commerce is a subset of e-commerce some of these papers were found very similar to the area under investigation, and were finally selected for the study. Thirdly, only Google Scholar was used for searching the papers due to convenience and credibility but it may not represent all the journals in this field. Although the number of studies were given as forty two, these are represented in 41 papers as one paper ${ }^{21}$, which is equivalent to two papers in this context since it compared the m-commerce adoption between a developed (US) and a developing country (China). Finally, some relevant papers were found to be available in Google Scholar but these were not accessible by the authors since the relevant journals were not subscribed to by their institutions.

\section{Implications of the Review}

The purpose of this research was to conduct a comprehensive review of literature that studied the determinants affecting m-commerce adoption. The research has contributed to the body of knowledge by identifying a list of factors that affect m-commerce adoption, and compared their impact between developed and developing countries. In total 59 key factors were found to have been studied, most of them in developed countries. Perceived usefulness and perceived ease of use are the two most highly studied factors in this field where perceived usefulness was found to be significant in developing and developed countries by $80 \%$ and $85 \%$ empirical research respectively; but in case of perceived ease of use it was significant in only $50 \%$ and $62 \%$ of studies respectively.

Perceived usefulness (PU) and perceived ease of use (PEOU) are the two most dominant constructs of Technology Acceptance Model (TAM). PU is defined as "the degree to which a person believes that using a particular system would enhance his or her job performance"6(p.320); while PEOU is referred as "the degree to which the perspective user expects the target to be free of effort." ${ }^{, 6(p .320)}$. TAM has been used as a tool for successfully predicting the adoption of different 
technologies (e.g. word processors, e-mail, WWW, GSS, Hospital Information Systems) in different situations (e.g., time and culture) with different control factors (e.g., gender, organizational type and size) and different subjects such as undergraduate students, MBAs, and knowledge workers ${ }^{35}$. TAM has gained substantial empirical support over time, successfully predicting $40 \%$ of the variance in usage intention and behaviour $^{57}$. However our review focused particularly on m-commerce adoption found that in 8 out of 10 studies in developing countries PU to be significant in $\mathrm{m}$-commerce adoption; and in case of developed countries this ratio was 17 out of 20 . This means that the majority of the studies both in developing and the developed world found that perceived usefulness significantly affects user's intention to use m-commerce services. This result is supported by the prior research of the extended TAM in the context of m-commerce (see Refs. 31, 36, 61, 63) and e-commerce ${ }^{28,61}$. Therefore it can be said that consumers would not use $\mathrm{m}$-commerce services unless they perceive it to be useful for them ${ }^{15,61}$. Service providers and vendors of $\mathrm{m}$-commerce should focus on how to make mcommerce services really useful for the consumers such as by providing quality, fast and secured services anytime anywhere via the mobile device ${ }^{15,61}$.

Contradictory findings have emerged in case of perceived ease of use (PEOU) where only 6 out of the 12 studies found PEOU to be significant in developing countries, and 15 out of 24 in developed countries. Many studies did not find PEOU to affect user's intention to use m-commerce services (see Refs.15, 17, $21,28,37,47,48,61,63)$. A group of researchers undertook two studies on PEOU and found opposite results; effect of PEOU on user's intention to use mcommerce service were found to have negative effects in their first study and positive effects in the second study $^{15}$. It was explained by saying that as the first study was of undergraduates who were knowledgeable and had strong capacity to learn new things, PEOU was not important for them to use m-commerce services but for the second sample it was found to be important as that sample was mixed up with various types of people of the country ${ }^{15}$. It was supported by other researchers also who believe that PEOU should not be an influential factor of m-commerce adoption as majority of the mobile users are youths who love exploring and learning new things, thus ease of use does not affect their intention to use $\mathrm{m}$-commerce ${ }^{26,61}$. PEOU might not have a direct affect on user's intention to use mcommerce services, but found to have some influence on PU for m-commerce adoption (Refs. 26, 31, 37, 47, 48, 49, 63). Therefore service providers should not ignore the effect of ease of use when designing an mcommerce platform as that will indirectly influence user intention to use m-commerce services such as through PU or attitude.

Research has however; found that it is not sufficient to explain a user's intention to accept technology using just two determinants: perceived ease-of-use and perceived usefulness as proposed by the $\mathrm{TAM}^{26}$. Therefore researchers were keen to extend TAM model with more factors. Some better models were also proposed that can explain adoption of advanced technologies more accurately. Examples of some models are Diffusion on Innovation (DOI) ${ }^{53}$; the Technology, Organization, and Environment (TOE) Framework ${ }^{56}$; TAM- $2^{57}$; Unified Theory of Acceptance and Use of Technology (UTAUT) ${ }^{58}$ and UTAUT $-2^{59}$. The dominant factors used in UTAUT are performance expectancy (equivalent to PU), effort expectancy (equivalent to PEOU), facilitating condition and social influence ${ }^{58}$. The researchers of UTAUT also showed how the relationship between performance expectancy (or effort expectancy) and intention to use can be moderated by age, gender, and experience ${ }^{41,58}$. For example, the link between performance expectancy and intention to use is more significant for male and younger workers ${ }^{51}$. On the other hand the effect of effort expectancy on intention is more significant for female and older workers, and it starts decreasing with experience $^{41}$. The UTAUT model explained $70 \%$ of the variance in usage intention, much better than the TAM studies alone (see Refs. 41, 51, 58).

In an m-commerce transaction in particular, consumers' intentions to participate should be seen as a multidimensional behavioural factor ${ }^{8}$ and hence all the models including TAM, TAM-2, UTAUT and UTAUT2 were extended by many researchers with many factors under different context such as privacy (see Refs. 8, 13, 21), perceived cost (See Refs. 3, 12, 15, 18, 21, 22, 31, 46, 61, 63), perceived security (see Refs. 3, 8, 9, 13, 31), perceived risk (see Refs. 3, 8, 9, 13, 22, 31, 63), trust (see Refs. 26, 36, 38, 54), speed (see Refs. 8, 13, 46), quality (see Refs. 9, 14, 16, 26, 32), convenience (see Refs. 3, 8, 12), compatibility (see Refs. 13, 21, 26, $37,40,63$ ) and many more as referred to in Appendix C. A summary of the literature review with its implications has been categorized below. The readers are advised to see the Appendix $\mathrm{C}$ for relevant citations or evidences.

\subsection{Factors resulted in mixed findings both in developed and developing countries}

Researchers found mixed or contradictory results about some factors that affect m-commerce adoption. Examples of these factors are PU, PEOU, perceived privacy, perceived cost, social influence, compatibility, self-efficacy, perceived enjoyment, quality and 
customization and trust. Perceived cost, trust and perceived privacy are among the top listed factors, besides PU and PEOU that are already discussed, that resulted in contradictory results. Trust was considered from different perspectives in various studies such as trust on internet, trust in vendors, trust on bank, trust on wireless, trust on e-channel and etc. (see Appendix C). The factor 'trust' was tested empirically by two studies in developing countries and in both cases it was found to be significant. The effect of trust is seen to be more contradictory in developed countries where 6 out of 14 studies, meaning more than $40 \%$ studies, did not find trust to have any significant effect on the adoption of $\mathrm{m}$-commerce. It may not be surprising when considered in the context of developed countries where law and order is applied more strictly compared to developing countries; as a result the service providers such as banks, telcos and government usually do not attempt to mislead their clients, thus people may not have experience of distrust and may not be able to evaluate the effect of it properly. Study found that trust in mobile banking adoption is strongly influenced by structural assurances ${ }^{26}$. Therefore banks should build up fast, secured and advanced platform of mobile banking services to ensure that customers are able to make transactions through mobile network without the fear of risk, fraud and uncertainties. Perceived cost (PC) has drawn some contradictory findings too, accounting the percentage of studies found $\mathrm{PC}$ to be significant in developing and developed countries are $84 \%$ and $75 \%$ respectively. It means that people in developing countries are more price sensitive than those in developed countries which makes sense.

\subsection{Factors always found to be significant in developing countries}

There are some factors never found to be insignificant in developing countries such as perceived risk, perceived security, trust, experience, subjective norm, complexity and personal innovativeness. But in developed countries these factors resulted in mixed findings. This means that people in the developing countries are more cautious about these issues than people in developed countries.

\subsection{Factors always found to be significant in developed countries}

Some factors were never found to be insignificant in developed countries but in developing countries; example of these factors are awareness, convenience, facilitating condition, speed and structural assurance. Therefore the vendors and other stake holders of mcommerce in developed countries should consider these factors while providing their $\mathrm{m}$-commerce services.

\subsection{Factors always found to be significant both in developed and developing countries}

Examples of these factors are attitude, performance expectancy and perceived reliability. Although some researchers did not find any link between attitude and user's intention to use technology 55 , in case of $\mathrm{m}$ commerce attitude was found to be always significant in both developed and developing countries. Performance expectancy has been introduced in UTAUT model ${ }^{58}$ and tested out to be the most influential factor affecting user's intention to adopt technology; but only one research paper ${ }^{38}$ was found to have studied that factor for $\mathrm{m}$-commerce adoption. More research should be conducted to fill this gap.

\subsection{Factors never studied in developing countries}

Surprisingly there are a number of factors that were never studied empirically in developing countries for m-commerce adoption; such as reputation, perceived image, satisfaction with past transaction, mobility, frequency, word of mouth, availability, self-control, flexibility, job relevance, result demonstrability, selfexpressiveness, perceived playfulness, limited capacity, enhanced communication feature, content reliability, speed, management support, market orientation and structural assurance. All these factors have been studied more or less in developed countries so far. Had these factors been studied in developing countries, research on m-commerce adoption would have been enriched.

\subsection{Factors never studied in developed countries}

There are some factors that have never been studied in developed countries but were in the developing world. For example, perceived credibility, normative pressure, peer-influence, government e-readiness, effort expectancy, mobile skilfulness, anxiety, perceived elitisation, rich \& fast information, standardisation and accessibility. Surprisingly all these were found to be significant except for perceived credibility in developing countries. The authors believe that all of these factors, that have not been studied yet either in developed or developing countries, if studied could have been found significant in the adoption of $\mathrm{m}$ commerce for that particular region; and would have help the stakeholders to redesign their strategies for mcommerce uptake.

\subsection{The effect of moderating factors such as age, gender, education and income}

Age, gender, education and income are usually considered as moderating factors that indirectly affect user's intention to use technology. A study found that "the influence of performance expectancy on 
behavioural intention is moderated by gender and age, such that the effect is stronger for men and particularly for younger men"58(pp.450). Unfortunately none of the studies of m-commerce adoption, except for one, that found any of the above mentioned moderating factors to be significant in either developed or developing countries $^{11}$. It might be interesting to explore why the effect of age, gender, education and income in the adoption of $\mathrm{m}$-commerce is very low or negligible.

\section{Conclusion and Future research directions}

This paper has presented a review of the literature on m-commerce adoption and contrasts the studies based in developed and developing countries. The purpose was to identify any research gap that could be addressed by researchers in their future work. As mentioned earlier a number of factors were never found to have been studied in developing countries but developed countries and vice versa. For example reputation, perceived image, satisfaction with past transaction, mobility, frequency, word of mouth, availability, selfcontrol, flexibility, job relevance, result demonstrability, self-expressiveness, perceived playfulness, limited capacity, enhanced communication feature, content reliability, speed, management support, market orientation and structural assurance have never been studied in developing countries, but were found to be significant in many studies of developed countries. Therefore there is a scope of studying these factors in developing countries that will enrich the models of mcommerce adoption. Similarly other factors such as perceived credibility, normative pressure, peerinfluence, government e-readiness, effort expectancy, mobile skilfulness, anxiety, perceived elitisation, rich \& fast information, standardisation and accessibility could be used to see the adoption of m-commerce in developed countries since these were not studied in developed countries yet.

The number of longitudinal research studies was found to be much lower than the number of cross sectional research studies in the field m-commerce adoption. Longitudinal research has great demand in any filed as it shows how people's perception on any issue could change overtime, and we need to see that trend in the perception of m-commerce adoption also.

Further, comparative studies of m-commerce adoption between developed and developing countries could have been conducted to see how the user's perceptions on the same factor impact differently in two different situations, and enable the identification of factors that are effective in developing countries but are perhaps not as effective as in the developed world.
It would be interesting to study the link between personal awareness of m-commerce and media advertising to make clear to stakeholders the effectiveness of their advertising. Government regulation, not studied precisely here, could be investigated to understand how it affects a country's adoption of m-commerce. It would be worthwhile to see how a company's performance, growth, reputation, solvency and profitability can impact the adoption of m-commerce.

\section{References}

1. J. Zhang, \& Y. Yuan, 'M-Commerce vs. E-Commerce, Key Differences', Americas Conference on Information Systems (AMCIS), 2002, p.1891-1901.

2. H. Feng, T. Hoegler, \& W. Stucky, 'Exploring the Critical Success Factors for Mobile Commerce', Proceedings of the International Conference on Mobile Business (ICMB'06), 2006, pp.1-8.

3. A. Islam, M. Khan, T. Ramayah, \& M. Hossain, 'The Adoption of Mobile Commerce Service among Employed Mobile Phone Users in Bangladesh: Selfefficacy as A Moderator', International Business Research, Vol. 4, No. 2, April 2011, pp. 80-89.

4. K. Slabeva, 'Towards a reference model for m-commerce application', Proceeding to European Conference on Information System (ECIS) 2002.

5. E.W.T. Ngai, \& A. Gunasekaran, 'A review for mobile commerce research and applications', Decision Support Systems, 43 (2007) 3 - 15.

6. F.D. Davis, 'Perceived Usefulness, Perceived Ease of Use, and User Acceptance of Information Technology', MIS Quarterly, 13(3), 1989, p.319-340.

7. F.D. Davis, 'User acceptance of information technology: system characteristics, user perceptions, and behavioral impacts', International Journal of Man Machine Studies, 38, 1993, p.475-487.

8. B. Anckar, C. Carlsson, \& P. Walden, 'Factors Affecting Consumer Adoption Decisions of m-Commerce', 16th Bled E-Commerce Conference, 2003, pp.886-902.

9. P.S. Bamoriya \& P. Singh, 'Issues \& challenges in mobile banking in India: a customers' perspective', Research Journal of Finance and Accounting, 2(2), 2011, 112-120.

10. F. Belanger \& L. Carter, 'Trust and risk in e-government adoption. The Journal of Strategic Information Systems, 17(2), 2008, 165-176.

11. E. Bigne, C. Ruiz, \& S. Sanz, 'Key Drivers of mcommerce adoption: An exploratory study of Spanish mobile users', Journal of Theoretical and Applied Electronic Commerce Research, 2(2), 2007, p.48-60.

12. R.A. Boadi, R. Boateng, R. Hinson \& R.A. Opoku, 'Preliminary Insights into M-commerce Adoption in Ghana', Information Development (ISSN 0266-6669), 23(4), 2007, p.253-265. 
13. L.D. Chen, 'A model of consumer acceptance of mobile payment,' Inderscience Enterprises Ltd., 6(1), 2008, p.32-52.

14. Z. Chen \& A.J. Dubinsky, 'A conceptual model of perceived customer value in ecommerce: A preliminary investigation', Psychology \& Marketing, 20(4), 2003, 323-347.

15. X. Cheng \& L. Wang, 'A comparative study of consumers' acceptance model in mobile-commerce', In Computer Engineering and Technology (ICCET), 2010 2nd International Conference on (Vol. 7, pp. V7-637). IEEE.

16. J. Cheong \& M. Park, 'Mobile Internet acceptance in Korea', Internet Research 15 (2), 2005, 125-140.

17. W.G. Chismar \& S. Wiley-patton, 'Does the extended technology acceptance model apply to physicians,' Proceedings of the 36th Hawaii International Conference on System Sciences, 2003, p.1-8.

18. J.W. Choi, H.J. Seol, S.J. Lee, H.Y. Cho, \& Y.T. Park, 'Customer satisfaction factors of mobile commerce in Korea', Internet Research, 18(3), 2008, 313-334.

19. B.J. Corbitt, T. Thanasankit \& H. Yi, 'Trust and ecommerce: a study of consumer perceptions,' Electronic Commerce Research \& Applications, Vol. 2 No. 3, 2003, pp. 203-15.

20. M. Crabbe, C. Standing, S. Standing, \& H. Karjaluoto, 'An adoption model for mobile banking in Ghana', International Journal of Mobile Communications, 7(5), 2009, 515-543.

21. H. Dai \& P.C. Palvia, 'Mobile Commerce Adoption in China and the United States: A Cross-Cultural Study,' The DATA BASE for Advances in Information Systems, 40(4),2009, pp.43 - 61.

22. J. Drennan \& L. Wessels, 'An investigation of consumer acceptance of M-Banking in Australia', Proceedings of Australian and New Zealand Marketing Academy Conference 2009. Sustainable Management and Marketing, 30 November - 2 December 2009, Monash University, Melbourne, Victoria.

23. M. Fishbein \& I. Ajzen, 'Belief, Attitude, Intention, and Behavior: An Introduction to Theory and Research', Addison- Wesley, Reading, MA, 1975.

24. D. Gefen \& D.W. Straub, 'Consumer trust in B2C ecommerce and the importance of social presence: experiments in e-products and e-services', Omega, Vol. 32, 2004, pp. 407-24.

25. S. Schwiderski-Grosche \& H. Knospe, 'Secure mobile commerce', Electronics \& Communication Engineering Journal, 14(5), 2002, 228-238.

26. J.C. Gu, S.C. Lee, \& Y.H. Suh, 'Determinants of behavioral intention to mobile banking', Elsevier Ltd., p.1-12, 2009.

27. S. AlAwadhi \& A. Morris, 'The Use of the UTAUT Model in the Adoption of E-government Services in Kuwait', In Hawaii International Conference on System Sciences, Proceedings of the 41st Annual (pp. 219-219), 2008, IEEE.
28. N. Jahangir \& N. Begum, 'The role of perceived usefulness, perceived ease of use, security and privacy, and customer attitude to engender customer adaptation in the context of electronic banking. African Journal of Business Management, Vol. 2 No. 1, 2008, pp. 32-40.

29. ITU Factsheet, 'The world in 2013, ICT Facts and figures', Accessed on $27^{\text {th }}$ August 2013 http://www.itu.int/en/ITU/Statistics/Documents/facts/ICTFactsFigures2013.pdf

30. ITU Key Statistics, 'Key ICT indicators for developed and developing countries and the world', Accessed on $27^{\text {th }} \quad$ August 2013 http://webcache.googleusercontent.com/search? $q=$ cache :F4aMc3cCaOOJ:www.itu.int/en/ITUD/Statistics/Documents/statistics/2013/ITU_Key_20052013_ICT_data.xls + Key $+I C T+$ indicators + for + develope $d+$ and + developing + countries + and + the + world $+($ totals + and + penetration + rates $) \& c d=1 \& h l=e n \& c t=c l n k \& g l=a u$

31. M. Khalifa \& N.K. Shen, 'Explaining the adoption of transactional B2C mobile commerce', Journal of Enterprise Information Management, Vol. 21 No. 2, 2008, pp. 110-24.

32. K.K. Kim \& B. Prabhakar, 'Initial trust and the adoption of B2C e-commerce: The case of internet banking', $A C M$ SIGMIS Database, 35, 2004, 50-64.

33. I.M. Klopping \& E. Mckiinneyy, 'Extending the Technology Acceptance Model and the Task-Technology Fit Model to Consumer E-Commerce', Information Technology, Learning, and Performance 22(1), 2004, p.35-47.

34. M. Koufaris, 'Applying the technology acceptance model and flow theory to online consumer behavior', Information Systems Research 13 (2), 2002, pp. 205-223.

35. Y. Lee, K.A. Kozar \& K.R.T. Larsen, 'The technology acceptance model: Past, present, and future', Communications of the Association for Information Systems (Volume 12, Article 50), 2003, 752-780.

36. J. Lu, C. Liu, C.S. Yu \& J.E. Yao, 'Exploring Factors Associated with Wireless Internet via Mobile Technology Acceptance in Mainland China', Communications of the International Information Management Association, , 3(1), 2003, p.101-120.

37. H.P. $\mathrm{Lu} \&$ P.Y.J. Su, 'Factors affecting purchase intention on mobile shopping web sites', Internet Research, 19(4), 2009, 442-458.

38. X. Luo, H. Li, J. Zhang \& J.P. Shim, 'Examining multidimensional trust and multi-faceted risk in initial acceptance of emerging technologies: an empirical study of mobile banking services', Decision Support Systems, Vol. 49 No. 2, 2010, pp. 222-34.

39. P. Mahatanankoon \& J. Vila-Ruiz, 'Why Won't Consumers Adopt M-Commerce- An Exploratory Study', Journal of Internet Commerce, 6(4), 2008, p.113-128.

40. N. Mallat, M. Rossi, V.K. Tuunainen \& A. Oorni, 'The impact of use context on mobile service acceptance: the case of mobile ticketing', Information \& Management 46:190-195, 2009. 
41. J.T. Marchewka \& C. Liu, 'An application of UTAUT Model for Understanding students perception using Management software', Communications of the IIMA, 7(2), 2007, p.93-104.

42. P. Meso, P. Musa \& V. Mbarika 'Towards a model of consumer use of mobile information and communication technology in LDCs: the case of sub-Saharan Africa', Info Systems J, 15, 2005, p.119-146.

43. A. Molla \& P.S. Licker, 'Perceived e-readiness factors in e-commerce adoption: an empirical investigation in a developing country', International Journal of Electronic Commerce, 10(1), 2005, 83-110.

44. K. O'Reilly, S. Goode \& D. Hart, 'Exploring mobile commerce intention: Evidence from Australia', In Communications and Information Technologies (ISCIT), 2010 International Symposium on (pp. 1120-1125). IEEE

45. H. Nysveen, P.E. Pedersen \& H. Thorbjørnsen, 'Intentions to use mobile services: antecedents and crossservice comparisons', Journal of the Academy of Marketing Science, 33(3), 2005, 330-346.

46. M. Pagani, 'Determinants of adoption of third generation mobile Multimedia services', Journal of Interactive Marketing Volume, 18(3), 2004, p.46-59.

47. P.A. Pavlou, 'Consumer acceptance of electronic commerce - integrating trust and risk with the technology acceptance model', International Journal of Electronic Commerce, Vol. 7 No. 3, 2003, pp. 101-34.

48. P.E. Pedersen, 'Adoption of mobile internet services: an exploratory study of mobile commerce early adopters', Journal of Organizational Computing and Electronic Commerce, Vol. 15 No. 3, 2005, pp. 203-221

49. P.E. Pedersen \& H. Nysveen, 'Usefulness and SelfExpressiveness: Extending TAM to Explain the Adoption of a Mobile Parking Service', 16th Bled eCommerce Conference, 2003, p.705-717.

50. PWC, 'Making waves: Southeast Asia series Spotlight The Philippines Accessed on $27^{\text {th }}$ August 2013 http://www.pwc.com/en_MY/my/assets/publications/maki ng-waves philippines.p $\bar{d} f$

51. E.M.V. Raaij \& J.J.L. Schepers, 'The acceptance and use of a virtual learning environment in China. Computers \& Education 50, 2008, p.838-852.

52. M.M. Rahman, 'Barriers to M-commerce Adoption in Developing Countries - A Qualitative Study among the Stakeholders of Bangladesh, The International Technology Management Review, Vol. 3 (2013), No. 2, pp. 80-91.

53. E.M. Rogers, 'Diffusion of innovations, Fourth Edition ed., New York, Free Press, 1995.

54. S. Snowden, J. Spafford, R. Michaelides, \& J. Hopkins, 'Technology acceptance and m-commerce in an operational environment', Journal of Enterprise
Information Management, Vol. 19 No. 5, 2006, pp. 525539.

55. S. Taylor \& P.A. Todd, 'Understanding information technology usage: A test of competing models', Information Systems Research, 6(2), 1995, pp.144-76.

56. L. Tornatzky \& M. Fleischer, 'The process of technology innovation, Lexington, MA, Lexington Books, 1990.

57. V. Venkatesh \& F.D. Davis, 'A Theoretical Extension of the Technology Acceptance Model: Four Longitudinal Field Studies', INFORMS, 46(2), 2000, p.186-204.

58. V. Venkatesh, M.G. Morris, G.B. Davis, \& F.D. Davis, 'User Acceptance of Information Technology: Toward a Unifined View', MIS Quarterly, 27, 2003, p.425-478.

59. V. Venkatesh, J.Y. Thong \& X. Xu, 'Consumer acceptance and use of information technology: extending the unified theory of acceptance and use of technology', MIS quarterly, 36(1), 2012, 157-178.

60. P. Verdegem \& G. Verleye, 'User-centered EGovernment in practice -A comprehensive model for measuring user satisfaction', Government Information Quarterly, 26(3): 487-497, 2009.

61. T.T. Wei, G. Marthandan, A.Y.L. Chong, K.B. Ooi \& S. Arumugam, 'What drives Malaysian m-commerce adoption-An empirical analysis', Industrial Management \& Data Systems, 109(3), 2009, p.370-388.

62. World Bank report, 'Maximizing mobile - Information and communication for development 2012', Viewed on $25^{\text {th }}$ August 2013.

http://siteresources.worldbank.org/EXTINFORMATION ANDCOMMUNICATIONANDTECHNOLOGIES/Resour ces/IC4D-2012-Report.pdf

63. J. Wu \& S. Wang, "What drives mobile commerce? An empirical evaluation of the revised technology acceptance model Science Direct', Information and Management, 42(2005) pp719-729.

64. F.D. Davis, R.P. Bagozzi \& P.R. Warshaw, 'User Acceptance of Computer Technology: A Comparison of Two Theoretical Models', INFORMS, 35(8), 1989, p.982-1003.

65. I. Ajzen, 'The Theory of Planned Behavior,' Organizational Behaviora nd Human D ecision Processes (50:2), 1991, pp. 179-211.

66. G.C. Moore \& I. Benbasat, 'Integrating Diffu-sion of Innovations and Theory of Reasoned Action Models to Predict Utilization of Infor-mationT echnologyb y EndUsers,' in Diffusion and Adoption of Information Technology, K. Kautz and J. Pries-Hege (eds.), Chapman and Hall, London, 1996, pp. 132-146.

67. R.L. Thompson, C.A. Higgins \& J.M. Howell, 'Personal Computing: Toward a Conceptual Model of Utilization,' IS Quarterly, (15:1), 1991, pp. 124-143 


\section{$\underline{\text { Appendix A: }}$ Definitions of some key factors effecting m-commerce adoption}

\begin{tabular}{|l|l|}
\hline Factor & Definition \\
\hline $\begin{array}{l}\text { Perceived Usefulness } \\
\text { (PU) }\end{array}$ & $\begin{array}{l}\text { Perceived usefulness (PU) is defined as "the degree to which a person believes that } \\
\text { using a particular system would enhance his or her job performance" }\end{array}$ (pp.320). \\
\hline $\begin{array}{l}\text { Perceived ease of use } \\
\text { (PEOU) }\end{array}$ & $\begin{array}{l}\text { Perceived ease of use (PEOU) referred as "the degree to which the perspective user } \\
\text { expects the target to be free of effort" (pp.320) }\end{array}$ \\
\hline Attitude (Att.) & $\begin{array}{l}\text { An individual's positive or negative feelings about performing the target } \\
\text { behaviour }\end{array}$ \\
\hline Perces,64
\end{tabular}

\section{Appendix B: Factors affecting m-commerce adoption - comparatively studied between developed and developing countries}

\begin{tabular}{|l|c|c|c|c|}
\hline \multirow{2}{*}{ Factors } & \multicolumn{4}{c|}{ Number of studies } \\
\cline { 2 - 5 } & \multicolumn{3}{|c|}{ Developed countries } & \multicolumn{2}{c|}{ Developing countries } \\
\cline { 2 - 5 } & Significant & Not Significant & Significant & Not Significant \\
\hline Perceived Usefulness (PU) & 17 & 3 & 8 & 2 \\
\hline Perceived ease of use (PEOU) & 15 & 9 & 6 & 6 \\
\hline Perceived Risk (PR) & 6 & 4 & 3 & 0 \\
\hline Perceived Privacy (PP) & 2 & 1 & 2 & 1 \\
\hline Perceived Security (PS) & 2 & 1 & 3 & 0 \\
\hline Trust (T) & 8 & 6 & 2 & 0 \\
\hline Reputation & 2 & 1 & 0 & 0 \\
\hline Perceived Credibility & 0 & 0 & 1 & 1 \\
\hline Perceived Image & 1 & 1 & 0 & 0 \\
\hline Experience & 5 & 2 & 1 & 0 \\
\hline Satisfaction with past transaction & 1 & 0 & 0 & 0 \\
\hline Mobility & 1 & 0 & 0 & 0 \\
\hline Attitude (Att.) & 7 & 0 & 2 & 0 \\
\hline Awareness/ Knowledge & 3 & 0 & 1 & 1 \\
\hline Perceived Cost & 6 & 2 & 5 & 1 \\
\hline
\end{tabular}

(Table continued to the next page) 


\begin{tabular}{|c|c|c|c|c|}
\hline \multirow[t]{3}{*}{ Factors } & \multicolumn{4}{|c|}{ Number of studies } \\
\hline & \multicolumn{2}{|c|}{ Developed countries } & \multicolumn{2}{|c|}{ Developing countries } \\
\hline & Significant & Not Significant & Significant & Not Significant \\
\hline Gender & 0 & 1 & 0 & 2 \\
\hline Age & 1 & 1 & 0 & 1 \\
\hline Education & 0 & 1 & 0 & 2 \\
\hline Income & 0 & 1 & 0 & 1 \\
\hline Frequency & 1 & 2 & 0 & 0 \\
\hline Word of mouth & 1 & 0 & 0 & 0 \\
\hline Availability & 0 & 1 & 0 & 0 \\
\hline Social/cultural Influence & 3 & 3 & 4 & 3 \\
\hline Subjective Norm (SN) & 2 & 4 & 1 & 0 \\
\hline Normative pressure & 0 & 0 & 1 & 0 \\
\hline Self/Behavioural Control & 4 & 1 & 0 & 0 \\
\hline Peer Influence & 0 & 0 & 1 & 0 \\
\hline Compatibility/ Familiarity & 4 & 1 & 2 & 1 \\
\hline Complexity & 1 & 1 & 2 & 0 \\
\hline Flexibility & 1 & 0 & 0 & 0 \\
\hline Convenience & 2 & 0 & 1 & 1 \\
\hline Govt. e-readiness & 0 & 0 & 1 & 0 \\
\hline Mobile Skilfulness & 0 & 0 & 1 & 0 \\
\hline Self-efficacy & 5 & 1 & 1 & 1 \\
\hline Facilitating Condition & 4 & 0 & 2 & 1 \\
\hline Effort Expectancy & 0 & 0 & 1 & 0 \\
\hline Performance Expectancy & 1 & 0 & 1 & 0 \\
\hline Job Relevance & 1 & 0 & 0 & 0 \\
\hline Result Demonstrability & 0 & 1 & 0 & 0 \\
\hline Self-Expressiveness & 2 & 1 & 0 & 0 \\
\hline Perceived Enjoyment & 3 & 1 & 1 & 1 \\
\hline Perceived Playfulness & 1 & 0 & 0 & 0 \\
\hline Personal Innovativeness & 1 & 2 & 1 & 0 \\
\hline Anxiety & 0 & 0 & 1 & 0 \\
\hline Limited capacity & 1 & 0 & 0 & 0 \\
\hline Enhanced communication feature & 1 & 0 & 0 & 0 \\
\hline Perceived Elitisation & 0 & 0 & 1 & 0 \\
\hline Quality & 6 & 1 & 0 & 1 \\
\hline Perceived Reliability & 1 & 0 & 1 & 0 \\
\hline Perceived value added & 1 & 1 & 0 & 1 \\
\hline Content Reliability & 1 & 0 & 0 & 0 \\
\hline Speed or Slow connection & 3 & 0 & 0 & 0 \\
\hline Rich \& Fast information & 0 & 0 & 1 & 0 \\
\hline Customization or Customer service & 2 & 1 & 0 & 1 \\
\hline Management support & 0 & 1 & 0 & 0 \\
\hline Standardisation & 0 & 0 & 1 & 0 \\
\hline Market orientation & 1 & 1 & 0 & 0 \\
\hline Structural Assurance & 3 & 0 & 0 & 0 \\
\hline Accessibility & 0 & 0 & 1 & 0 \\
\hline
\end{tabular}




\section{Appendix C: Factors affecting m-commerce adoption: Comparatively studied between developed and developing countries}

The table below shows the relationship: Factor $\rightarrow$ Intention to use (I), if not specified otherwise

\begin{tabular}{|c|c|c|c|}
\hline Factors & Context & Found Highly Significant in & Not Significant, found in \\
\hline \multirow{25}{*}{$\begin{array}{l}\text { Perceived } \\
\text { Usefulness } \\
\text { (PU) }\end{array}$} & \multirow{8}{*}{$\begin{array}{l}\text { Developing } \\
\text { countries }\end{array}$} & M-commerce adoption in China ${ }^{15}$ & M-commerce adoption in Bangladesh ${ }^{3}$ \\
\hline & & $(M \text {-banking adoption in Ghana: } P U \rightarrow \text { Att. \& I })^{20}$ & \multirow{7}{*}{$\begin{array}{l}\text { (Mobile ICT adoption in sub Saharan Africa: } \\
P U \rightarrow \text { Business \& socializing use of mobile ICT) }\end{array}$} \\
\hline & & $\left(M\right.$-commerce adoption in US \& China $^{2 I}$ & \\
\hline & & M-internet adoption in China ${ }^{36}$ & \\
\hline & & M-shopping adoption in Taiwan $^{37}$ & \\
\hline & & (e-banking adoption in Bangladesh: $P U \rightarrow$ Att. \& I) ${ }^{28}$ & \\
\hline & & M-commerce adoption-Malaysia ${ }^{61}$ & \\
\hline & & M-commerce adoption in Taiwan ${ }^{63}$ & \\
\hline & \multirow{17}{*}{$\begin{array}{l}\text { Developed } \\
\text { Countries }\end{array}$} & M-payment adoption in $\mathrm{US}^{13}$ & M-ticketing adoption in Finland ${ }^{40}$ \\
\hline & & $\left(\mathrm{M}\right.$-internet adoption in S. Korea: PU $\rightarrow$ Att. \& I) ${ }^{16}$ & \multirow{4}{*}{$\begin{array}{l}\text { (M-services adoption in Norway : PU } \rightarrow \text { Intention } \\
\text { to use more goal directed mobile services (i.e. SMS } \\
\& \text { payment) than the intention to use experimental } \\
\text { mobile services (i.e. contact \& gaming) } \text { (5) }^{45}\end{array}$} \\
\hline & & e-health adoption in Hawaii ${ }^{17}$ & \\
\hline & & 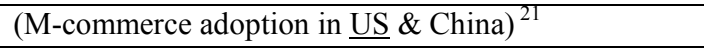 & \\
\hline & & (M-banking adoption in Australia) $^{22}$ & \\
\hline & & $(\text { M-banking adoption in Korea) })^{26}$ & M-internet adoption in US, Europe $\& \mathrm{Asia}^{48}$ \\
\hline & & (M-internet adoption in US, Europe \& & \\
\hline & & M-commerce adoption in Hong Kong ${ }^{31}$ & \\
\hline & & Trust on internet banking in $\mathrm{US}^{32}$ & \\
\hline & & Online Shopping adoption in US ${ }^{33}$ & \\
\hline & & (e-shopping adoption in US: & \\
\hline & & M-services adoption in Norway ${ }^{45}$ & \\
\hline & & M-commerce adoption in Australia: $\mathrm{PU} \rightarrow \mathrm{Att}^{44}$ & \\
\hline & & Mobile multimedia adoption in Italy ${ }^{46}$ & \\
\hline & & e-commerce adoption ${ }^{47}$ & \\
\hline & & (M-parking adoption in Norway: PU $\rightarrow$ Att. \& I) ${ }^{49}$ & \\
\hline & & Mobile ICT adoption in $\mathrm{UK}^{54}$ & \\
\hline \multirow{21}{*}{$\begin{array}{l}\text { Perceived } \\
\text { ease of use } \\
\text { (PEOU) }\end{array}$} & \multirow{6}{*}{$\begin{array}{l}\text { Developing } \\
\text { countries }\end{array}$} & $(M \text {-banking adoption-Ghana: PEOU } \rightarrow \text { Att. })^{20}$ & M-commerce in China ${ }^{15}$ \\
\hline & & $(M \text {-commerce adoption in US \& } \text { China })^{21}$ & (e-banking adoption in Bangladesh: PEOU $\rightarrow I.)^{28}$ \\
\hline & & (e-banking adoption in Bangladesh: PEOU $\rightarrow$ Att. $)^{28}$ & (M-shopping adoption in Taiwan: $P E O U \rightarrow I)^{37}$ \\
\hline & & (Mobile shopping adoption in Taiwan: & (mobile ICT adoption in sub Saharan Africa: \\
\hline & & M-internet adoption in China ${ }^{36}$ & M-commerce adoption in Malaysia ${ }^{61}$ \\
\hline & & $(M \text {-commerce in adoption Taiwan PEOU } \rightarrow P U)^{63}$ & (M-commerce adoption in Taiwan: $P E O U \rightarrow I)^{63}$ \\
\hline & \multirow{15}{*}{$\begin{array}{l}\text { Developed } \\
\text { Countries }\end{array}$} & (online shopping adoption in US: & e-health adoption in Hawaii ${ }^{17}$ \\
\hline & & M-payment adoption in US ${ }^{13}$ & $(\mathrm{M} \text {-commerce in US \& China })^{21}$ \\
\hline & & (M-commerce in Hong Kong: PEOU $\rightarrow \mathrm{PU})^{31}$ & (M-banking adoption in Australia: PEOU $\rightarrow$ Att.) ${ }^{22}$ \\
\hline & & (M-banking adoption in Korea: PEOU $\rightarrow$ PU \& I) ${ }^{26}$ & (M-banking adoption in Korea: PEOU $\rightarrow$ Trust) ${ }^{26}$ \\
\hline & & Trust on internet banking in $\mathrm{US}^{32}$ & (M-commerce in Hong Kong: PEOU $\rightarrow$ PU) $)^{31}$ \\
\hline & & (M-internet adoption in Korea: & (e-shopping adoption in US: \\
\hline & & Online Shopping adoption in US ${ }^{33}$ & E-commerce adoption $^{47}$ \\
\hline & & M-ticketing adoption in Finland ${ }^{40}$ & M-internet adoption in US, Europe \& Asia $^{48}$ \\
\hline & & M-services adoption in Norway ${ }^{45}$ & (M-internet adoption in Norway: PEOU $\rightarrow$ Att. $)^{49}$ \\
\hline & & (M-commerce adoption in Australia: PU $\rightarrow$ Att.) ${ }^{44}$ & \\
\hline & & Mobile multimedia adoption in Italy ${ }^{46}$ & \\
\hline & & $(\text { E-commerce adoption: PEOU } \rightarrow \text { PU \& I })^{47}$ & \\
\hline & & $(\mathrm{M} \text {-parking adoption in Norway: PEOU } \rightarrow \mathrm{PU})^{49}$ & \\
\hline & & (M-internet adoption in US, Europe \& Asia: & \\
\hline & & Mobile ICT adoption in $\mathrm{UK}^{54}$ & \\
\hline
\end{tabular}

(Table continued to the next page) 
The table below shows the relationship: Factor $\rightarrow$ Intention to use (I), if not specified otherwise

\begin{tabular}{|c|c|c|c|}
\hline Factors & Context & Found Highly Significant in & Not Significant, found in \\
\hline \multirow[t]{10}{*}{ Trust (T) } & \multirow[t]{2}{*}{$\begin{array}{l}\text { Developing } \\
\text { countries }\end{array}$} & $\begin{array}{l}\text { (M-internet adoption in China: } \\
\text { Trust in m-internet } \rightarrow I)^{36}\end{array}$ & \\
\hline & & $M$-commerce adoption in Malaysia ${ }^{61}$ & \\
\hline & \multirow[t]{8}{*}{$\begin{array}{l}\text { Developed } \\
\text { Countries }\end{array}$} & $\begin{array}{l}\text { (E-govt. adoption in US: } \\
\text { Trust on internet } \rightarrow \text { I, Trust on Gov. } \rightarrow \mathrm{I})^{10}\end{array}$ & $\begin{array}{l}\text { (E-govt. adoption in US: } \\
\text { Trust on Internet } \rightarrow \text { Lower Risk) }\end{array}$ \\
\hline & & $\begin{array}{l}\text { (E-govt. adoption in US: } \\
\text { Trust on Govt. } \rightarrow \text { Lower Risk) }{ }^{10}\end{array}$ & $\begin{array}{l}\text { (Perception in e-commerce in New Zealand: } \\
\text { Trust } \rightarrow \text { PR) })^{19}\end{array}$ \\
\hline & & $\begin{array}{l}\text { (e-commerce adoption in New Zealand: } \\
\text { Trust worthiness } \rightarrow \text { Trust })^{19}\end{array}$ & $\begin{array}{l}\text { (Trust on e-commerce in US: } \\
\text { Trust in vendor ability } \rightarrow \text { I) }\end{array}$ \\
\hline & & $\begin{array}{l}\text { (Trust on e-commerce in US: } \\
\text { Trust in vendor integrity \& predictability } \rightarrow \text { I) } \\
\end{array}$ & $\begin{array}{l}\text { (Trust on internet banking in US: } \\
\text { Trust on bank } \rightarrow \mathrm{I})^{32}\end{array}$ \\
\hline & & (M-banking adoption in Korea: Trust $\rightarrow$ I \& PU) ${ }^{26}$ & $\begin{array}{l}\text { (Trust } \& \text { risk on M-banking in } \\
\text { US: Trust on bank } \rightarrow I \& P R)^{38}\end{array}$ \\
\hline & & $\begin{array}{l}\text { (Trust on internet banking in } \\
\text { US: Trust on e-channel } \rightarrow \mathrm{I})^{32}\end{array}$ & $\begin{array}{l}\text { (Trust \& risk on M-banking in US: Trust } \rightarrow \\
\text { performance expectancy) }\end{array}$ \\
\hline & & $\begin{array}{l}\text { (E-commerce adoption: } \\
\text { Trust } \rightarrow \text { I, PR, PU \& PEOU) }{ }^{47}\end{array}$ & \\
\hline & & $\begin{array}{l}\text { (Mobile ICT adoption in UK: } \\
\text { Wireless Trust } \rightarrow \text { PU) } \\
\text { 54 }\end{array}$ & \\
\hline \multirow{9}{*}{$\begin{array}{l}\text { Perceived } \\
\text { risk }(P R)\end{array}$} & \multirow{3}{*}{$\begin{array}{l}\text { Developing } \\
\text { countries }\end{array}$} & M-banking adoption in India ${ }^{9}$ & \\
\hline & & M-commerce adoption in Bangladesh ${ }^{3}$ & \\
\hline & & M-commerce adoption in Taiwan ${ }^{63}$ & \\
\hline & \multirow{6}{*}{$\begin{array}{l}\text { Developed } \\
\text { Countries }\end{array}$} & M-payment adoption in US ${ }^{13}$ & \multirow[t]{2}{*}{ M-commerce adoption in Finland ${ }^{8}$} \\
\hline & & (M-banking adoption in Australia: PR $\rightarrow$ Att. $)^{22}$ & \\
\hline & & (M-commerce adoption in Hong Kong: PR $\rightarrow$ PU) ${ }^{31}$ & e-govt. adoption -US ${ }^{10}$ \\
\hline & & $\begin{array}{l}\text { (Trust \& risk on M-banking in US: } \\
\text { PR } \rightarrow \text { I \& Performance expectancy) }\end{array}$ & $\begin{array}{l}\text { (online shopping adoption in US: } \\
\text { PR } \rightarrow \text { Customer value) })^{14}\end{array}$ \\
\hline & & (M-commerce adoption in Australia: PR $\rightarrow$ Att.) ${ }^{44}$ & (Perception in e-commerce in New Zealand: \\
\hline & & E-commerce adoption $^{47}$ & $\mathrm{PR} \rightarrow{\text { Trust })^{19}}^{2}$ \\
\hline \multirow{4}{*}{$\begin{array}{l}\text { Perceived } \\
\text { privacy } \\
(\mathrm{PP})\end{array}$} & \multirow{2}{*}{$\begin{array}{l}\text { Developing } \\
\text { countries }\end{array}$} & M-banking adoption in India ${ }^{9}$ & $(M \text {-commerce adoption in US \& } \underline{\text { China }})^{21}$ \\
\hline & & (e-banking adoption in Bangladesh: $P P \rightarrow I \&$ Att. $)^{28}$ & \\
\hline & \multirow{2}{*}{$\begin{array}{l}\text { Developed } \\
\text { Countries }\end{array}$} & $(\mathrm{M} \text {-payment adoption in US: } \mathrm{PP} \rightarrow \mathrm{PR})^{13}$ & \multirow[t]{2}{*}{ M-commerce adoption in Finland ${ }^{8}$} \\
\hline & & $(\text { M-commerce adoption in } \underline{\text { US }} \& \text { China })^{21}$ & \\
\hline \multirow[t]{3}{*}{$\begin{array}{l}\text { Reputation } \\
\text { (RP) }\end{array}$} & $\begin{array}{l}\text { Developing } \\
\text { Countries }\end{array}$ & & \\
\hline & \multirow[t]{2}{*}{$\begin{array}{l}\text { Developed } \\
\text { Countries }\end{array}$} & $\begin{array}{l}\text { (Online shopping adoption in US: } \\
\mathrm{RP} \rightarrow \text { Product quality) }\end{array}$ & \multirow[t]{2}{*}{$(\text { Online shopping adoption in US: } \mathrm{RP} \rightarrow \mathrm{PR})^{14}$} \\
\hline & & $(\text { E-commerce adoption: } \mathrm{RP} \rightarrow \text { Trust })^{47}$ & \\
\hline \multirow{2}{*}{$\begin{array}{l}\text { Perceived } \\
\text { credibility } \\
\text { (PCr) }\end{array}$} & $\begin{array}{l}\text { Developing } \\
\text { countries }\end{array}$ & $\begin{array}{l}\text { (M-banking adoption in Ghana: } \\
P C r \rightarrow I \& \text { Att. })^{20}\end{array}$ & $\begin{array}{l}\text { (M-commerce adoption in China: } \\
P C r \rightarrow I \& P U)^{15}\end{array}$ \\
\hline & $\begin{array}{l}\text { Developed } \\
\text { Countries }\end{array}$ & & \\
\hline \multirow{2}{*}{$\begin{array}{l}\text { Perceived } \\
\text { image } \\
\text { (PI) }\end{array}$} & $\begin{array}{l}\text { Developing } \\
\text { countries }\end{array}$ & & \\
\hline & $\begin{array}{l}\text { Developed } \\
\text { Countries }\end{array}$ & 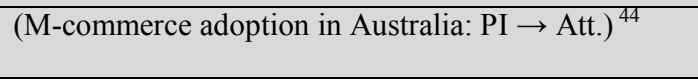 & (e-health adoption in Hawaii: PI $\rightarrow$ PU) $^{17}$ \\
\hline \multirow{2}{*}{$\begin{array}{l}\text { Satisfaction } \\
\text { with past } \\
\text { transaction } \\
\text { (SPT) }\end{array}$} & $\begin{array}{l}\text { Developing } \\
\text { countries }\end{array}$ & & \\
\hline & $\begin{array}{l}\text { Developed } \\
\text { Countries }\end{array}$ & 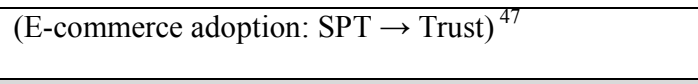 & \\
\hline \multirow[t]{2}{*}{$\begin{array}{l}\text { Mobility } \\
\text { (Mb) }\end{array}$} & $\begin{array}{l}\text { Developing } \\
\text { Countries }\end{array}$ & & \\
\hline & $\begin{array}{l}\text { Developed } \\
\text { Countries }\end{array}$ & $\begin{array}{l}\text { (M-ticketing adoption in Finland: } \\
\mathrm{Mb} \rightarrow \mathrm{I}, \text { mediated by use context) }\end{array}$ & \\
\hline
\end{tabular}

(Table continued to the next page) 
The table below shows the relationship: Factor $\rightarrow$ Intention to use (I), if not specified otherwise

\begin{tabular}{|c|c|c|c|}
\hline Factors & Context & Found Highly Significant in & Not Significant, found in \\
\hline \multirow[t]{6}{*}{$\begin{array}{l}\text { Experience } \\
\text { (Exp) }\end{array}$} & $\begin{array}{l}\text { Developing } \\
\text { countries }\end{array}$ & $\begin{array}{l}\text { (E-govt. adoption in Kuwait: } \\
\left.\text { Internet Exp. Moderates }{ }^{I} P E \rightarrow I \&{ }^{2} E E \rightarrow I\right)^{27}\end{array}$ & \\
\hline & \multirow[t]{5}{*}{$\begin{array}{l}\text { Developed } \\
\text { Countries }\end{array}$} & $\begin{array}{l}\text { (M-commerce adoption in Spain: } \\
\text { length of mobile use } \rightarrow I)^{11}\end{array}$ & $\begin{array}{l}\text { (M-commerce adoption in Spain: } \\
\text { Internet Shopping Exp. } \rightarrow \text { I \& Att. })^{11}\end{array}$ \\
\hline & & $\begin{array}{l}\text { (M-commerce in Spain: } \\
\text { M-commerce Exp. } \rightarrow \text { Attitude) })^{11}\end{array}$ & $\begin{array}{l}\text { (Perception in e-commerce in New Zealand: } \\
\text { Web Exp. } \rightarrow \text { PR) }{ }^{19}\end{array}$ \\
\hline & & $\begin{array}{l}\text { (M-internet adoption in S. Korea: } \\
\text { Internet Exp. } \rightarrow \text { PEOU \& Playfulness) }\end{array}$ & \\
\hline & & $\begin{array}{l}\text { (Online shopping adoption in US: } \\
\text { Exp } \rightarrow \text { Customer value \& Product quality) }{ }^{14}\end{array}$ & \\
\hline & & $\begin{array}{l}\text { (Perception in e-commerce in New Zealand: } \\
\text { Web Exp. } \rightarrow \text { Trust) }{ }^{19}\end{array}$ & \\
\hline \multirow{9}{*}{$\begin{array}{l}\text { Attitude } \\
\text { (Att.) }\end{array}$} & \multirow{2}{*}{$\begin{array}{l}\text { Developing } \\
\text { countries }\end{array}$} & 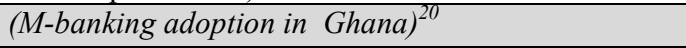 & \\
\hline & & (e-banking adoption in Bangladesh) ${ }^{28}$ & \\
\hline & \multirow{7}{*}{$\begin{array}{l}\text { Developed } \\
\text { Countries }\end{array}$} & M-commerce adoption in Spain ${ }^{11}$ & \\
\hline & & M-internet adoption in Korea ${ }^{16}$ & \\
\hline & & $(\text { IT adoption in US: Att. } \rightarrow \text { Actual usage })^{7}$ & \\
\hline & & $(\text { M-banking adoption in Australia })^{22}$ & \\
\hline & & M-commerce adoption in Australia ${ }^{44}$ & \\
\hline & & M-parking adoption in Norway ${ }^{49}$ & \\
\hline & & M-internet adoption in US, Europe \& Asia $^{48}$ & \\
\hline \multirow{5}{*}{$\begin{array}{l}\text { Perceived } \\
\text { security } \\
\text { (PS) }\end{array}$} & \multirow{3}{*}{$\begin{array}{l}\text { Developing } \\
\text { countries }\end{array}$} & M-banking adoption in India $^{9}$ & \\
\hline & & M-commerce adoption in Bangladesh ${ }^{3}$ & \\
\hline & & 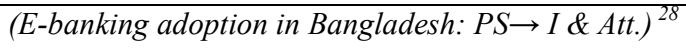 & \\
\hline & \multirow{2}{*}{$\begin{array}{l}\text { Developed } \\
\text { Countries }\end{array}$} & $(\mathrm{M} \text {-payment adoption in US: PS } \rightarrow \mathrm{PR})^{13}$ & \multirow[t]{2}{*}{ M-commerce adoption in Finland ${ }^{8}$} \\
\hline & & (M-commerce adoption in Hong Kong: PS $\rightarrow \mathrm{PU})^{31}$ & \\
\hline \multirow{4}{*}{$\begin{array}{l}\text { Awareness } \\
\text { (Aw) } \\
\text { / } \\
\text { Knowledge } \\
\text { (K) }\end{array}$} & $\begin{array}{l}\text { Developing } \\
\text { countries }\end{array}$ & (E-commerce adoption in $S$. Africa: $A w \rightarrow I)^{43}$ & $\begin{array}{l}(M \text {-commerce adoption in Bangladesh: } \\
A w \rightarrow I)^{3}\end{array}$ \\
\hline & \multirow[t]{3}{*}{$\begin{array}{l}\text { Developed } \\
\text { Countries }\end{array}$} & $\begin{array}{l}\text { (M-commerce adoption in US: Consumer's } \\
\text { unawareness was found significant) }\end{array}$ & \\
\hline & & $\begin{array}{l}\text { (Mobile multimedia adoption in Italy: } \\
\mathrm{K} \rightarrow \text { Interest) }\end{array}$ & \\
\hline & & $\begin{array}{l}\text { (User satisfaction on E-govt. in Flemish population : } \\
\text { Awareness required in finding the service) }\end{array}$ & \\
\hline \multirow{11}{*}{$\begin{array}{l}\text { Perceived } \\
\text { cost } \\
(\mathrm{PC})\end{array}$} & \multirow{5}{*}{$\begin{array}{l}\text { Developing } \\
\text { countries }\end{array}$} & M-commerce adoption in Ghana ${ }^{I 2}$ & M-commerce adoption in China ${ }^{15}$ \\
\hline & & $(M \text {-commerce adoption in US \& } \underline{\text { China }})^{21}$ & \\
\hline & & M-commerce adoption in Bangladesh ${ }^{3}$ & \\
\hline & & M-commerce adoption in Malaysia ${ }^{61}$ & \\
\hline & & M-commerce adoption in Taiwan ${ }^{63}$ & \\
\hline & \multirow{6}{*}{$\begin{array}{l}\text { Developed } \\
\text { Countries }\end{array}$} & M-commerce adoption in Finland ${ }^{8}$ & $\left(\mathrm{M}\right.$-commerce adoption in $\underline{\text { US } \& \text { China })^{21}}$ \\
\hline & & $\begin{array}{l}\text { (M-internet adoption in S. Korea: } \\
\text { Price } \rightarrow \text { Att. \& I) }\end{array}$ & M-commerce adoption in S. Korea ${ }^{18}$ \\
\hline & & $\begin{array}{l}\text { (Online shopping adoption in US: } \\
\text { Price } \rightarrow \text { PR) }\end{array}$ & \\
\hline & & $\begin{array}{l}\text { (M-banking adoption in Australia: } \\
\mathrm{PC} \rightarrow \text { Att. \& I) }\end{array}$ & \\
\hline & & $\begin{array}{l}\text { (M-commerce adoption in Hong Kong: } \\
\mathrm{PC} \rightarrow \mathrm{PU})^{31}\end{array}$ & \\
\hline & & Mobile multimedia adoption in Italy ${ }^{46}$ & \\
\hline \multirow[t]{2}{*}{ Availability } & $\begin{array}{l}\text { Developing } \\
\text { countries }\end{array}$ & & \\
\hline & $\begin{array}{l}\text { Developed } \\
\text { Countries }\end{array}$ & & $\begin{array}{l}\text { M-commerce adoption in S. Korea: } \\
\text { Availability } \rightarrow \text { User satisfaction) }{ }^{18}\end{array}$ \\
\hline
\end{tabular}

(Table continued to the next page) 
M.M. Rahman, T. Sloan / Cross-cultural comparison of m-commerce adoption

The table below shows the relationship: Factor $\rightarrow$ Intention to use (I), if not specified otherwise

\begin{tabular}{|c|c|c|c|}
\hline Factors & Context & Found Highly Significant in & Not Significant, found in \\
\hline \multirow[t]{3}{*}{ Gender } & \multirow{2}{*}{$\begin{array}{l}\text { Developin } \\
\text { g countries }\end{array}$} & & (E-govt. adoption in Kuwait) $^{27}$ \\
\hline & & & Mobile ICT adoption in Sub Saharan Africa ${ }^{42}$ \\
\hline & $\begin{array}{l}\text { Developed } \\
\text { Countries }\end{array}$ & & M-commerce adoption in Spain ${ }^{11}$ \\
\hline \multirow[t]{2}{*}{ Age } & $\begin{array}{l}\text { Developin } \\
\text { g countries }\end{array}$ & & Mobile ICT adoption in Sub Saharan Africa ${ }^{42}$ \\
\hline & $\begin{array}{l}\text { Developed } \\
\text { Countries }\end{array}$ & $\begin{array}{l}\text { (M-commerce adoption in Spain: } \\
\text { Age } \rightarrow \text { Frequency of mobile use, } \\
\text { Age } \rightarrow \text { length of mobile use, Age } \rightarrow \text { I \& } \\
\text { Age } \rightarrow \text { Frequency of m-commerce use) }{ }^{11}\end{array}$ & Mobile multimedia adoption in Italy ${ }^{46}$ \\
\hline \multirow[t]{3}{*}{ Education } & \multirow{2}{*}{$\begin{array}{l}\text { Developin } \\
\text { g countries }\end{array}$} & & M-banking adoption in Ghana ${ }^{20}$ \\
\hline & & & Mobile ICT adoption in Sub Saharan Africa ${ }^{42}$ \\
\hline & $\begin{array}{l}\text { Developed } \\
\text { Countries }\end{array}$ & & M-commerce adoption in Spain ${ }^{11}$ \\
\hline \multirow[t]{2}{*}{ Income } & $\begin{array}{l}\text { Developin } \\
\text { g countries }\end{array}$ & & M-banking adoption in Ghana ${ }^{20}$ \\
\hline & $\begin{array}{l}\text { Developed } \\
\text { Countries }\end{array}$ & & M-commerce adoption in Spain ${ }^{11}$ \\
\hline \multirow[t]{3}{*}{ Frequency } & $\begin{array}{l}\text { Developin } \\
\text { g countries }\end{array}$ & & \\
\hline & \multirow[t]{2}{*}{$\begin{array}{l}\text { Developed } \\
\text { Countries }\end{array}$} & $\begin{array}{l}\text { (M-commerce adoption in Spain: Frequency of } \\
\text { mobile use } \rightarrow \text { Frequency of m-commerce })^{11}\end{array}$ & $\begin{array}{l}\text { (M-commerce adoption in Spain: } \\
\text { Frequency of mobile use } \rightarrow \mathrm{I})^{11}\end{array}$ \\
\hline & & & $\begin{array}{l}(\text { E-commerce adoption : } \\
\text { Frequency } \rightarrow \text { Trust })^{47}\end{array}$ \\
\hline \multirow[t]{2}{*}{$\begin{array}{l}\text { Word of } \\
\text { mouth }\end{array}$} & $\begin{array}{l}\text { Developin } \\
\text { g countries }\end{array}$ & & \\
\hline & $\begin{array}{l}\text { Developed } \\
\text { Countries }\end{array}$ & $\begin{array}{l}\text { (Trust on internet banking in US: } \\
\text { Word of mouth } \rightarrow \text { trust on e-channel) }{ }^{32}\end{array}$ & \\
\hline \multirow{3}{*}{$\begin{array}{l}\text { Social } \\
\text { Influence } \\
\text { (SI) }\end{array}$} & \multirow{4}{*}{$\begin{array}{l}\text { Developin } \\
\text { g countries }\end{array}$} & $(M \text {-commerce adoption in China: } S I \rightarrow I)^{15}$ & $(M \text {-banking adoption in Ghana: } S I \rightarrow I)^{20}$ \\
\hline & & $\begin{array}{l}\text { (M-commerce adoption in US \& China: } \\
S I \rightarrow I)^{2 I}\end{array}$ & $(M \text {-internet adoption in China: } S I \rightarrow I)^{36}$ \\
\hline & & $\begin{array}{l}\text { (Mobile ICT adoption in sub-Saharan Africa: } \\
C I \rightarrow P E O U)^{42}\end{array}$ & $\begin{array}{l}\text { (Mobile ICT adoption in sub-Saharan } \\
\text { Africa: } C I \rightarrow I)\end{array}$ \\
\hline \multirow{4}{*}{$\begin{array}{l}\text { Cultural } \\
\text { Influence } \\
\text { (CI) }\end{array}$} & & $\begin{array}{l}\text { (M-commerce adoption in Malaysia: } \\
S I \rightarrow I)^{61}\end{array}$ & \\
\hline & \multirow[t]{3}{*}{$\begin{array}{l}\text { Developed } \\
\text { Countries }\end{array}$} & $\begin{array}{l}\text { (Trust on e-commerce in US: } \\
\text { Higher social presence } \rightarrow \text { Trust in venders } \\
\text { integrity \& predictability) }\end{array}$ & $\begin{array}{l}\text { (M-commerce adoption in Finland: Social } \\
\text { Status not Significant) }\end{array}$ \\
\hline & & (M-banking adoption in Korea $(\mathrm{SI} \rightarrow \mathrm{PU})^{26}$ & $\begin{array}{l}(\mathrm{M} \text {-commerce adoption in US \& China: } \\
\mathrm{SI} \rightarrow \mathrm{I})^{21}\end{array}$ \\
\hline & & (Mobile ICT adoption in UK: SI $\rightarrow$ PU) ${ }^{54}$ & $\begin{array}{l}\text { (Trust on e-commerce in US: } \\
\text { Higher social presence } \rightarrow \text { Trust in } \\
\text { venders ability) }\end{array}$ \\
\hline \multirow{5}{*}{$\begin{array}{l}\text { Subjective } \\
\text { Norm } \\
\text { (SN) }\end{array}$} & $\begin{array}{l}\text { Developin } \\
\text { g countries }\end{array}$ & $(M \text {-commerce adoption in US \& } \underline{\text { China }})^{21}$ & \\
\hline & \multirow[t]{4}{*}{$\begin{array}{l}\text { Developed } \\
\text { Countries }\end{array}$} & $\begin{array}{l}\text { (M-commerce adoption in Hong Kong: } \\
\mathrm{SN} \rightarrow \mathrm{PU})^{31}\end{array}$ & 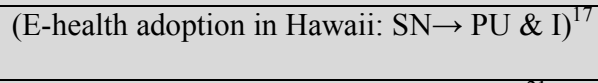 \\
\hline & & \multirow{3}{*}{$\begin{array}{l}\text { (M-commerce adoption in Australia: } \\
\mathrm{SN} \rightarrow \mathrm{I})^{44}\end{array}$} & 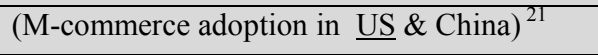 \\
\hline & & & $\begin{array}{l}\text { (M-commerce adoption in Hong Kong: } \\
\mathrm{SN} \rightarrow \mathrm{I})^{31}\end{array}$ \\
\hline & & & $\begin{array}{l}\text { (M-internet adoption in US, Europe \& Asia: } \\
\mathrm{SN} \rightarrow \text { Att.\& I) }\end{array}$ \\
\hline
\end{tabular}

(Table continued to the next page) 
M.M. Rahman, T. Sloan / Cross-cultural comparison of m-commerce adoption

The table below shows the relationship: Factor $\rightarrow$ Intention to use (I), if not specified otherwise

\begin{tabular}{|c|c|c|c|}
\hline Factors & Context & Found Highly Significant in & Not Significant, found in \\
\hline \multirow{2}{*}{$\begin{array}{l}\text { Normative } \\
\text { Pressure } \\
\text { (NP) }\end{array}$} & $\begin{array}{l}\text { Developing } \\
\text { countries }\end{array}$ & & \\
\hline & $\begin{array}{l}\text { Developed } \\
\text { Countries }\end{array}$ & M-services adoption in Norway ${ }^{45}$ & \\
\hline \multirow[t]{2}{*}{$\begin{array}{l}\text { Self-Control } \\
\text { (SC) }\end{array}$} & $\begin{array}{l}\text { Developing } \\
\text { countries }\end{array}$ & & \\
\hline & \multirow[t]{4}{*}{$\begin{array}{l}\text { Developed } \\
\text { Countries }\end{array}$} & $(\mathrm{M} \text {-services adoption in Norway: } \mathrm{BC} \rightarrow \mathrm{I})^{45}$ & $\begin{array}{l}\text { (E-shopping adoption in US: } \\
\text { Perceived Control } \rightarrow \text { Intention to return) }\end{array}$ \\
\hline \multirow{3}{*}{$\begin{array}{l}\text { \& } \\
\text { Behavioural } \\
\text { Control } \\
\text { (BC) }\end{array}$} & & $\begin{array}{l}\text { (M-commerce adoption in Australia: } \\
\mathrm{BC} \rightarrow \mathrm{I})^{44}\end{array}$ & \\
\hline & & $\begin{array}{l}\text { (M-internet adoption in US, Europe \& Asia: } \\
\mathrm{BC} \rightarrow \mathrm{I})^{48}\end{array}$ & \\
\hline & & $\begin{array}{l}\text { (M-internet adoption in US, Europe \& Asia: } \\
\mathrm{SC} \rightarrow \text { Subjective Norm) }\end{array}$ & \\
\hline \multirow[t]{2}{*}{ Peer Influence } & $\begin{array}{l}\text { Developing } \\
\text { countries }\end{array}$ & 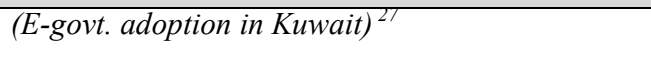 & \\
\hline & $\begin{array}{l}\text { Developed } \\
\text { countries }\end{array}$ & & \\
\hline \multirow[t]{2}{*}{ Flexibility } & $\begin{array}{l}\text { Developing } \\
\text { countries }\end{array}$ & & \\
\hline & $\begin{array}{l}\text { Developed } \\
\text { Countries }\end{array}$ & $\begin{array}{l}\text { (M-commerce adoption in Finland: } \\
\text { Flexibility was found significant) }\end{array}$ & \\
\hline \multirow{6}{*}{$\begin{array}{l}\text { Compatibility } \\
\text { Or } \\
\text { Familiarity }\end{array}$} & \multirow[t]{2}{*}{$\begin{array}{l}\text { Developing } \\
\text { countries }\end{array}$} & $\begin{array}{l}\text { (M-shopping adoption in Taiwan: } \\
\text { Compatibility } \rightarrow I)^{37}\end{array}$ & $\begin{array}{l}\text { (M-commerce adoption in US \& China: } \\
\text { Compatibility } \rightarrow I)^{2 I}\end{array}$ \\
\hline & & $\begin{array}{l}\text { (M-commerce adoption in Taiwan: } \\
\text { Compatibility } \rightarrow I \& P U)^{63}\end{array}$ & \\
\hline & \multirow[t]{4}{*}{$\begin{array}{l}\text { Developed } \\
\text { Countries }\end{array}$} & $(\mathrm{M} \text {-payment adoption in US: Compatibility } \rightarrow \mathrm{I})^{13}$ & $\begin{array}{l}\text { (M-banking adoption in Korea: } \\
\text { Familiarity with bank } \rightarrow \text { PEOU) }\end{array}$ \\
\hline & & $\begin{array}{l}\text { (M-commerce adoption in US \& China: } \\
\text { Compatibility } \rightarrow \mathrm{I})^{21}\end{array}$ & \\
\hline & & $\begin{array}{l}\text { (M-banking adoption in Australia: } \\
\text { Compatibility } \rightarrow \text { I \& Att.) }\end{array}$ & \\
\hline & & $\begin{array}{l}\text { (M-ticketing adoption in Finland: } \\
\text { Compatibility } \rightarrow \mathrm{I}) 40\end{array}$ & \\
\hline \multirow[t]{3}{*}{ Complexity } & \multirow[t]{2}{*}{$\begin{array}{l}\text { Developing } \\
\text { countries }\end{array}$} & $\begin{array}{l}\text { (M-banking adoption in India: } \\
\text { Operability of mobile handset })^{9}\end{array}$ & \\
\hline & & $\begin{array}{l}\text { (M-internet adoption in China: } \\
\text { System complexity } \rightarrow I)^{36}\end{array}$ & \\
\hline & $\begin{array}{l}\text { Developed } \\
\text { Countries }\end{array}$ & Mobile ICT adoption in $\mathrm{UK}^{54}$ & M-commerce adoption in Finland ${ }^{8}$ \\
\hline \multirow[t]{3}{*}{ Convenience } & $\begin{array}{l}\text { Developing } \\
\text { countries }\end{array}$ & M-commerce adoption in Ghana ${ }^{I L}$ & $\begin{array}{l}\text { (M-commerce adoption in Bangladesh: } \\
\text { convenience } \rightarrow I)^{3}\end{array}$ \\
\hline & \multirow[t]{2}{*}{$\begin{array}{l}\text { Developed } \\
\text { Countries }\end{array}$} & $\begin{array}{l}\text { (M-commerce adoption in Finland: } \\
\text { Flexibility was found significant) }\end{array}$ & \\
\hline & & $\begin{array}{l}\text { (M-payment adoption in US: } \\
\text { convenience } \rightarrow \text { PU) }\end{array}$ & \\
\hline \multirow[t]{2}{*}{$\begin{array}{l}\text { Govt. } \\
\text { e-readiness }\end{array}$} & $\begin{array}{l}\text { Developing } \\
\text { countries }\end{array}$ & $\begin{array}{l}\text { (E-commerce adoption in } S . \text { Africa: } \\
\text { Govt. e-readiness } \rightarrow I)^{43}\end{array}$ & \\
\hline & $\begin{array}{l}\text { Developed } \\
\text { Countries }\end{array}$ & & \\
\hline \multirow[t]{2}{*}{$\begin{array}{l}\text { Mobile } \\
\text { Skilfulness }\end{array}$} & $\begin{array}{l}\text { Developin } \\
\text { g countries }\end{array}$ & $\begin{array}{l}\text { (M-shopping adoption in Taiwan: } \\
\text { mobile skilfulness } \rightarrow P U, \text { Anxiety, Enjoyment })^{37}\end{array}$ & \\
\hline & $\begin{array}{l}\text { Developed } \\
\text { Countries }\end{array}$ & & \\
\hline \multirow[t]{3}{*}{$\begin{array}{l}\text { Self- } \\
\text { Expressiveness }\end{array}$} & $\begin{array}{l}\text { Developing } \\
\text { countries }\end{array}$ & & \\
\hline & \multirow[t]{2}{*}{$\begin{array}{l}\text { Developed } \\
\text { countries }\end{array}$} & $\begin{array}{l}\text { (M-services adoption in Norway: } \\
\text { Self-expressiveness } \rightarrow \mathrm{I})\end{array}$ & $\begin{array}{l}\text { (M-parking adoption in Norway: } \\
\text { Self-expressiveness } \rightarrow \text { Att.) }\end{array}$ \\
\hline & & $\begin{array}{l}\text { (M-parking adoption in Norway: } \\
\text { Self-expressiveness } \rightarrow \text { PU \& I) }\end{array}$ & \\
\hline
\end{tabular}

(Table continued to the next page) 
The table below shows the relationship: Factor $\rightarrow$ Intention to use (I), if not specified otherwise

\begin{tabular}{|c|c|c|c|}
\hline Factors & Context & Found Highly Significant in & Not Significant, found in \\
\hline \multirow{6}{*}{$\begin{array}{l}\text { Facilitating } \\
\text { Condition } \\
\text { (FC) }\end{array}$} & \multirow[t]{2}{*}{$\begin{array}{l}\text { Developing } \\
\text { countries }\end{array}$} & $\begin{array}{l}\text { (E-govt. adoption in Kuwait: } \\
F C \rightarrow \text { use Behaviour })^{27}\end{array}$ & M-internet adoption in China ${ }^{36}$ \\
\hline & & $\begin{array}{l}\text { (M-banking adoption in Ghana: } \\
F C \rightarrow \text { Att. \& I })^{20}\end{array}$ & \\
\hline & \multirow[t]{4}{*}{$\begin{array}{l}\text { Developed } \\
\text { Countries }\end{array}$} & $\begin{array}{l}\text { (M-banking adoption in Korea: } \\
\text { FC } \rightarrow \text { PEOU) }\end{array}$ & \\
\hline & & $\begin{array}{l}\text { (M-commerce adoption in Australia: } \\
\text { FC } \rightarrow \text { Behavioural control) }\end{array}$ & \\
\hline & & $\begin{array}{l}\text { (M-internet adoption in US, Europe \& Asia: } \\
\text { FC } \rightarrow \text { Behavioural control) }\end{array}$ & \\
\hline & & $\begin{array}{l}\text { (Mobile ICT adoption in UK: } \\
\text { FC } \rightarrow \text { PU \& PEOU) }\end{array}$ & \\
\hline \multirow{2}{*}{$\begin{array}{l}\text { Effort } \\
\text { Expectancy } \\
\text { (EE) }\end{array}$} & $\begin{array}{l}\text { Developing } \\
\text { countries }\end{array}$ & (E-govt. adoption in Kuwait: $E E \rightarrow I)^{27}$ & \\
\hline & $\begin{array}{l}\text { Developed } \\
\text { Countries }\end{array}$ & & \\
\hline \multirow{2}{*}{$\begin{array}{l}\text { Performance } \\
\text { Expectancy } \\
\text { (PE) }\end{array}$} & $\begin{array}{l}\text { Developing } \\
\text { countries }\end{array}$ & (E-govt. adoption in Kuwait: $P E \rightarrow I)^{27}$ & \\
\hline & $\begin{array}{l}\text { Developed } \\
\text { Countries }\end{array}$ & $(\text { Trust } \& \text { risk on } \mathrm{M} \text {-banking in US: } \mathrm{PE} \rightarrow \mathrm{I})^{38}$ & \\
\hline \multirow{2}{*}{$\begin{array}{l}\text { Job } \\
\text { Relevance } \\
\text { (JR) }\end{array}$} & $\begin{array}{l}\text { Developing } \\
\text { countries }\end{array}$ & & \\
\hline & $\begin{array}{l}\text { Developed } \\
\text { Countries }\end{array}$ & $(\text { E-health adoption in Hawaii: } \mathrm{JR} \rightarrow \mathrm{PU})^{17}$ & \\
\hline \multirow[t]{6}{*}{$\begin{array}{l}\text { Self-Efficacy } \\
\text { (SE) }\end{array}$} & $\begin{array}{l}\text { Developing } \\
\text { countries }\end{array}$ & $\begin{array}{l}\text { (M-commerce adoption in Bangladesh: } \\
\text { SE moderates rich \& fast info } \rightarrow I)^{3}\end{array}$ & $\begin{array}{l}\text { (M-commerce adoption in Bangladesh: } \\
S E \text { moderates awareness } \rightarrow I \text {, } \\
\text { convenience } \rightarrow I \text {, risk } \rightarrow I \& P U \rightarrow I)^{3}\end{array}$ \\
\hline & \multirow{5}{*}{$\begin{array}{l}\text { Developed } \\
\text { countries }\end{array}$} & $\left(\right.$ M-banking adoption in Korea: SE $\rightarrow$ PEOU) ${ }^{26}$ & \multirow{5}{*}{$\begin{array}{l}\text { (Trust \& risk on M-banking in US: SE } \rightarrow \\
\mathrm{PR}^{38}\end{array}$} \\
\hline & & $\begin{array}{l}\text { (M-commerce adoption in Hong Kong: } \\
\mathrm{SE} \rightarrow \text { PEOU \& I) })^{31}\end{array}$ & \\
\hline & & $\begin{array}{l}\text { (Trust } \& \text { risk on M-banking in US: } \\
\mathrm{SE} \rightarrow \text { Structural assurance) } \\
\end{array}$ & \\
\hline & & $\begin{array}{l}\text { (M-commerce adoption in Australia: } \\
\mathrm{SE} \rightarrow \text { Behavioural control) }\end{array}$ & \\
\hline & & $\begin{array}{l}\text { (M-internet adoption in US, Europe \& Asia: } \\
\mathrm{SE} \rightarrow \text { Behavioural control) }\end{array}$ & \\
\hline \multirow{2}{*}{$\begin{array}{l}\text { Result } \\
\text { Demonstrability } \\
\text { (RD) }\end{array}$} & $\begin{array}{l}\text { Developing } \\
\text { countries }\end{array}$ & & \\
\hline & $\begin{array}{l}\text { Developed } \\
\text { Countries }\end{array}$ & & ${\text { (E-health adoption in Hawaii: } \mathrm{RD} \rightarrow \mathrm{PU})^{17}}^{17}$ \\
\hline & & & \\
\hline \multirow[t]{4}{*}{$\begin{array}{l}\text { Perceived } \\
\text { Enjoyment }\end{array}$} & $\begin{array}{l}\text { Developing } \\
\text { countries }\end{array}$ & M-shopping adoption in Taiwan ${ }^{37}$ & 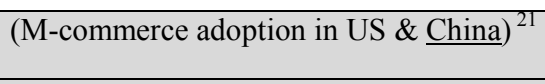 \\
\hline & \multirow[t]{3}{*}{$\begin{array}{l}\text { Developed } \\
\text { Countries }\end{array}$} & 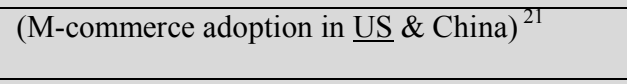 & $\begin{array}{l}\text { (M-commerce adoption in Finland: } \\
\text { Entertaining feature } \rightarrow \text { not Significant })^{8}\end{array}$ \\
\hline & & $\begin{array}{l}\text { (E-shopping adoption in US: } \\
\text { Shopping enjoyment } \rightarrow \text { Intention to return) }{ }^{34}\end{array}$ & \\
\hline & & M-services adoption in Norway ${ }^{45}$ & \\
\hline \multirow[t]{2}{*}{$\begin{array}{l}\text { Perceived } \\
\text { playfulness }\end{array}$} & $\begin{array}{l}\text { Developing } \\
\text { countries }\end{array}$ & & \\
\hline & $\begin{array}{l}\text { Developed } \\
\text { Countries }\end{array}$ & $\begin{array}{l}\text { (M-internet adoption in S. Korea: } \\
\text { Perceived playfulness } \rightarrow \text { Att. \& I) }\end{array}$ & \\
\hline \multirow[t]{2}{*}{ Standardization } & $\begin{array}{l}\text { Developing } \\
\text { countries }\end{array}$ & M-banking adoption in India ${ }^{9}$ & \\
\hline & $\begin{array}{l}\text { Developed } \\
\text { Countries }\end{array}$ & & \\
\hline
\end{tabular}


M.M. Rahman, T. Sloan / Cross-cultural comparison of m-commerce adoption

The table below shows the relationship: Factor $\rightarrow$ Intention to use (I), if not specified otherwise

\begin{tabular}{|c|c|c|c|}
\hline Factors & Context & Found Highly Significant in & Not Significant, found in \\
\hline \multirow[t]{3}{*}{$\begin{array}{l}\text { Personal } \\
\text { Innovativeness }\end{array}$} & $\begin{array}{l}\text { Developing } \\
\text { countries }\end{array}$ & $(M \text {-commerce adoption in US\& } \underline{\text { China }})^{21}$ & \\
\hline & \multirow[t]{2}{*}{$\begin{array}{l}\text { Developed } \\
\text { Countries }\end{array}$} & $(\mathrm{M} \text {-commerce adoption in US \& China })^{21}$ & $\begin{array}{l}\text { (M-commerce adoption in Australia: } \\
\text { Personal innovativeness } \rightarrow \text { Att.) }\end{array}$ \\
\hline & & & $\begin{array}{l}\text { (Mobile multimedia adoption in Italy: } \\
\text { Personal innovativeness - not significant) }\end{array}$ \\
\hline \multirow[t]{2}{*}{ Anxiety } & $\begin{array}{l}\text { Developing } \\
\text { countries }\end{array}$ & M-shopping adoption in Taiwan $^{37}$ & \\
\hline & $\begin{array}{l}\text { Developed } \\
\text { Countries }\end{array}$ & & \\
\hline \multirow{2}{*}{$\begin{array}{l}\text { Enhanced } \\
\text { communication } \\
\text { feature }\end{array}$} & $\begin{array}{l}\text { Developing } \\
\text { countries }\end{array}$ & & \\
\hline & $\begin{array}{l}\text { Developed } \\
\text { Countries }\end{array}$ & M-commerce adoption in Finland ${ }^{8}$ & \\
\hline \multirow[t]{2}{*}{$\begin{array}{l}\text { Perceived } \\
\text { Elitisation }\end{array}$} & $\begin{array}{l}\text { Developing } \\
\text { countries }\end{array}$ & M-banking adoption in Ghana ${ }^{20}$ & \\
\hline & $\begin{array}{l}\text { Developed } \\
\text { Countries }\end{array}$ & & \\
\hline \multirow[t]{2}{*}{ Accessibility } & $\begin{array}{l}\text { Developing } \\
\text { countries }\end{array}$ & $\begin{array}{l}\text { (Mobile ICT adoption in sub Saharan Africa: } \\
\text { Accessibility } \rightarrow P U \& P E O U)^{42}\end{array}$ & \\
\hline & $\begin{array}{l}\text { Developed } \\
\text { Countries }\end{array}$ & & \\
\hline \multirow[t]{7}{*}{ Quality } & $\begin{array}{l}\text { Developing } \\
\text { countries }\end{array}$ & & $\begin{array}{l}\text { (M-banking adoption in India: Telecom } \\
\text { service quality - not found significant) }\end{array}$ \\
\hline & \multirow[t]{6}{*}{$\begin{array}{l}\text { Developed } \\
\text { countries }\end{array}$} & $\begin{array}{l}\text { (M-internet adoption in S. Korea: } \\
\text { Content quality } \rightarrow \text { PU \& Playfulness) }\end{array}$ & Trust on internet banking in US $^{32}$ \\
\hline & & $\begin{array}{l}\text { (M-internet adoption in S. Korea: } \\
\text { System quality } \rightarrow \text { PU \& PEOU) }\end{array}$ & \\
\hline & & $\begin{array}{l}\text { (Online shopping adoption in US: } \\
\text { Product quality } \rightarrow \text { Customer value \& Risk) }\end{array}$ & \\
\hline & & $\begin{array}{l}\text { (E-health adoption in Hawaii: } \\
\text { Output quality } \rightarrow \text { PU) }{ }^{17}\end{array}$ & \\
\hline & & $\begin{array}{l}\text { (Perception in e-commerce in New Zealand: } \\
\text { Website quality } \rightarrow \text { Trust) }\end{array}$ & \\
\hline & & $\begin{array}{l}\text { (M-banking adoption in Korea: } \\
\text { System quality } \rightarrow \mathrm{PU})^{26}\end{array}$ & \\
\hline \multirow[t]{2}{*}{$\begin{array}{l}\text { Perceived } \\
\text { Reliability }\end{array}$} & $\begin{array}{l}\text { Developing } \\
\text { countries }\end{array}$ & Mobile ICT adoption in sub Saharan Africa ${ }^{42}$ & \\
\hline & $\begin{array}{l}\text { Developed } \\
\text { Countries }\end{array}$ & M-services adoption in Norway ${ }^{45}$ & \\
\hline \multirow[t]{2}{*}{$\begin{array}{l}\text { Perceived value } \\
\text { added }\end{array}$} & $\begin{array}{l}\text { Developing } \\
\text { countries }\end{array}$ & & $(M \text {-commerce adoption in US \& } \text { China })^{21}$ \\
\hline & $\begin{array}{l}\text { Developed } \\
\text { Countries }\end{array}$ & $\begin{array}{l}\text { (E-shopping adoption in US: } \\
\text { Perceived value added } \rightarrow \text { shopping enjoyment) }{ }^{34}\end{array}$ & $(\mathrm{M} \text {-commerce adoption in } \underline{\mathrm{US}} \& \text { China })^{21}$ \\
\hline \multirow[t]{2}{*}{$\begin{array}{l}\text { Content } \\
\text { Reliability }\end{array}$} & $\begin{array}{l}\text { Developing } \\
\text { countries }\end{array}$ & & \\
\hline & $\begin{array}{l}\text { Developed } \\
\text { Countries }\end{array}$ & $\begin{array}{l}\text { (M-commerce adoption in S. Korea: } \\
\text { Content reliability } \rightarrow \text { User satisfaction })^{18}\end{array}$ & \\
\hline \multirow{4}{*}{$\begin{array}{l}\text { Speed } \\
\text { \&/or } \\
\text { Slow connection }\end{array}$} & $\begin{array}{l}\text { Developing } \\
\text { countries }\end{array}$ & & \\
\hline & \multirow[t]{3}{*}{$\begin{array}{l}\text { Developed } \\
\text { Countries }\end{array}$} & $\begin{array}{l}\text { (M-commerce adoption in Finland: } \\
\text { Slow connection } \rightarrow I)^{8}\end{array}$ & \\
\hline & & $(\text { M-payment adoption in US: Speed } \rightarrow \text { PU) })^{13}$ & \\
\hline & & $\begin{array}{l}\text { (Mobile multimedia adoption in Italy: } \\
\text { Speed of use } \rightarrow \text { I) }\end{array}$ & \\
\hline
\end{tabular}

(Table continued to the next page) 
M.M. Rahman, T. Sloan / Cross-cultural comparison of m-commerce adoption

The table below shows the relationship: Factor $\rightarrow$ Intention to use (I), if not specified otherwise

\begin{tabular}{|c|c|c|c|}
\hline Factors & Context & Found Highly Significant in & Not Significant, found in \\
\hline \multirow[t]{2}{*}{$\begin{array}{l}\text { Rich \& Fast } \\
\text { information }\end{array}$} & $\begin{array}{l}\text { Developin } \\
\text { g countries }\end{array}$ & M-commerce adoption in Bangladesh ${ }^{3}$ & \\
\hline & $\begin{array}{l}\text { Developed } \\
\text { Countries }\end{array}$ & & \\
\hline \multirow{3}{*}{$\begin{array}{l}\text { Customization } \\
\text { \&/or } \\
\text { Customer } \\
\text { service }\end{array}$} & $\begin{array}{l}\text { Developin } \\
\text { g countries }\end{array}$ & & M-banking adoption in India ${ }^{9}$ \\
\hline & \multirow[t]{2}{*}{$\begin{array}{l}\text { Developed } \\
\text { countries }\end{array}$} & $\begin{array}{l}\text { (Online shopping adoption in US: } \\
\text { Customer service } \rightarrow \text { Experience) }\end{array}$ & $\begin{array}{l}\text { (M-commerce adoption in S. Korea: } \\
\text { Customer service } \rightarrow \text { User satisfaction) })^{18}\end{array}$ \\
\hline & & $\begin{array}{l}\text { (M-commerce adoption in US: } \\
\text { Customization was found significant) }\end{array}$ & \\
\hline \multirow[t]{2}{*}{$\begin{array}{l}\text { Management } \\
\text { support }\end{array}$} & $\begin{array}{l}\text { Developin } \\
\text { g countries }\end{array}$ & & \\
\hline & $\begin{array}{l}\text { Developed } \\
\text { Countries }\end{array}$ & & Trust on internet banking in US ${ }^{32}$ \\
\hline \multirow[t]{2}{*}{$\begin{array}{l}\text { Market } \\
\text { Orientation }\end{array}$} & $\begin{array}{l}\text { Developin } \\
\text { g countries }\end{array}$ & & \\
\hline & $\begin{array}{l}\text { Developed } \\
\text { Countries }\end{array}$ & $\begin{array}{l}\text { (Perception in e-commerce in New Zealand: } \\
\text { Market Orientation } \rightarrow \text { Trust) }\end{array}$ & $\begin{array}{l}\text { (Perception in e-commerce in New Zealand: } \\
\text { Market Orientation } \rightarrow \text { e-commerce } \\
\text { participation) }\end{array}$ \\
\hline \multirow[t]{4}{*}{$\begin{array}{l}\text { Structural } \\
\text { Assurance }\end{array}$} & $\begin{array}{l}\text { Developin } \\
\text { g countries }\end{array}$ & & \\
\hline & \multirow[t]{3}{*}{$\begin{array}{l}\text { Developed } \\
\text { Countries }\end{array}$} & $\begin{array}{l}\text { (M-banking adoption in Korea: } \\
\text { Structural assurance } \rightarrow \text { Trust) }\end{array}$ & \\
\hline & & $\begin{array}{l}\text { (Trust on internet banking In US: } \\
\text { Structural assurance } \rightarrow \text { Trust) }\end{array}$ & \\
\hline & & $\begin{array}{l}\text { (Trust } \& \text { risk on M-banking in US: } \\
\text { Structural assurance } \rightarrow \text { Perceived Risk) }\end{array}$ & \\
\hline \multirow[t]{2}{*}{$\begin{array}{l}\text { Limited } \\
\text { capacity }\end{array}$} & $\begin{array}{l}\text { Developin } \\
\text { g countries }\end{array}$ & & \\
\hline & $\begin{array}{l}\text { Developed } \\
\text { Countries }\end{array}$ & M-commerce adoption in Finland ${ }^{8}$ & \\
\hline
\end{tabular}

